\title{
THE HEALTH STATUS OF COMMERCIAL FISH IN THE MUŠOV LAKE
}

\author{
Z. LUCKÝ, S. NAVRÁTIL, MARCELAA JIRÁSKOVÁ \\ Department of Poultry, Fish, Bee and Game Diseases, \\ University of Veterinary Science, 61242 Brno \\ Dedicated to Professor MVDr. Václav Dyk, DrSc. \\ on the Occasion of his 75th Birthday
}

Received January 28, 1987

A b s $t r a c t$

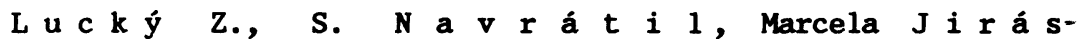
$k$ o a : The Health Status of Commercial Fish in the Mušov Lake. Acta vet. Brno, 58, 1989: 53-90.

Investigations into the health status of $f$ ish in the Musov lake performed in 1981 to 1985 showed 2 infectious diseases, 40 parasites and several pathological conditions in commercial fish (Esox lucius, Ctenopharyngodon idella, Tinca tinca, Cyprinus carpio, Stizostedion lucioperca) and 4 infectious diseases, 79 parasites and several pathological conditions in non-commercial fish species (Rutilus rutilus, Leuciscus idus, Sardinius erythrophthalmus, Alburnus alburbus, Blicca bjoerkna, Abramis brama. Carassius carassius, Perca fluviatilis, Gymnocephalus cernua). The sample of parasites in commercial fish, however, did not reach the number of parasitic species reported in earlier studies.

During the investigation several episodes of mass fish death occurred due to oxygen depletion in the lake. The most severe ones were recorded in January 1984 and the winter period of 1984-85 when nearly all of the fish died. The infectious and parasitic diseases are described in detail.

To control infections in carp several short-term bath procedures were tested and control measures were suggested to prevent death of fish due to oxygen deficiency.

Infectious disease, parasitic disease, antiparasitic bath, oxygen deficiency.

The Mušov pool built in 1978 is the first reservoir in the system of Nové Mlýny lakes. It is situated in the basin of the Dyje river $170 \mathrm{~m}$ above the sea level. This lake resulted from flooding the nonregulated area around 
the Dyje river below the town of Drnholec. The front dam of the lake, running about $500 \mathrm{~m}$ above the abolished village of Mušov, has a motor road (route Brno-Mikulov) on the top (Fig. 1 ).

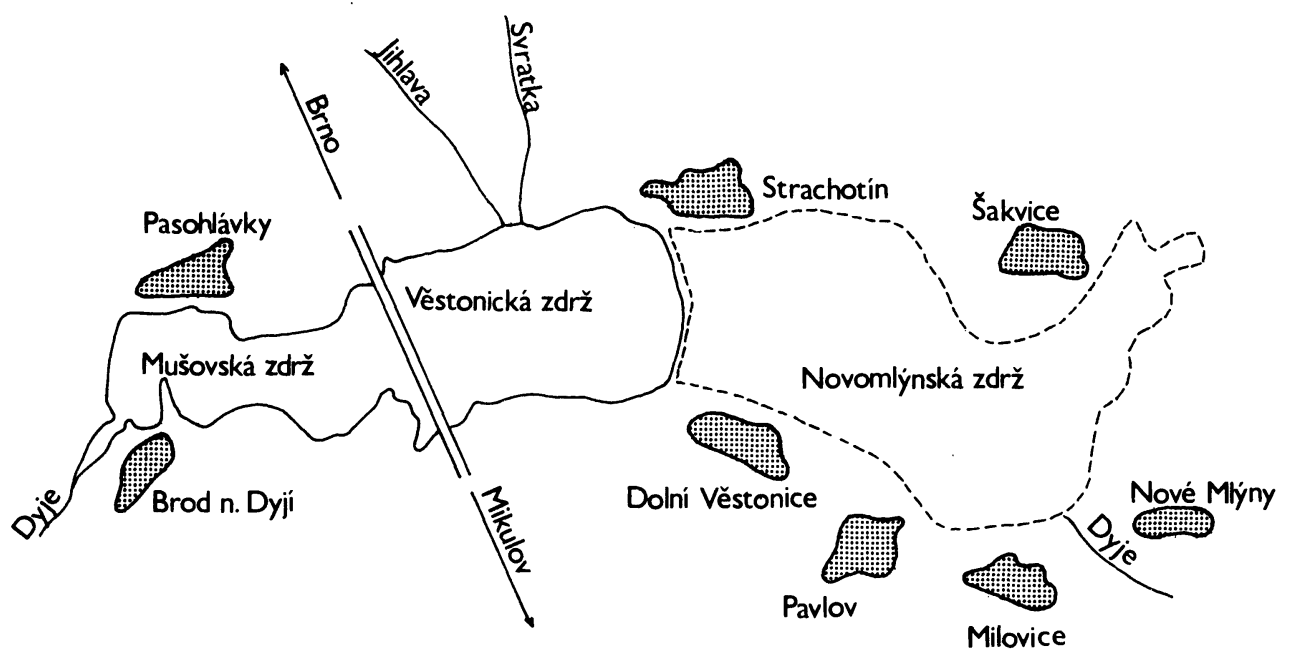

Fig. 1. The complex of South-Moravian lakes.

No research concerning fish health in the Mušov lake has been done so far. On the other hand, intensive studies have been carried out on the health status of $\mathrm{fish}$ in the attached pond systems managed by the State Fishery regional offices in Pohořelice-Velký Dvuir and in Hlohovec, and in streams and rivers of the catchment areas of Dyje, Jihlava and Svratka below the Mušov lake.

Investigation into fish infectious diseases in the area mentioned above began in about 1950 when many new lakes were founded in the river basins of Dyje, Jihlava and Svratka. The main interest was paid to breeder fish, particularly carp, in which infectious diseases and their aetiological agents were studied by the workers of the Department of Biology and Parasitic Diseases,University of Veterinary Science, Brno under the leadership of Prof $\mathrm{V}$. Dyk (D y k 1954). On the basis of this book and the inspection of laboratory records, the following infectious diseases were diagnosed: acute and ulcerative forms of infectious dropsy (spring viremia and erythrodermatitis), fish pox, infectious inflammation of the air-bladder in carp, ulcer disease of pikes and other fish species, branchiomycosis of carp and haemorrhagic septicaemia of tenches. Infectious diseases are reviewed and classified in a monograph ( $\mathrm{D} \mathrm{k}$ 1961), with numerous references to southern Moravia localities.

In the area mentioned above parasitic diseases were studied as early as in the 1930s. In 1933 Skrjabin s helminthological dissection method was used to investigate parasitic worms of bass species in Dyje near Sakvice ( $\mathrm{V}$ e $\mathrm{j} n$ a $\mathrm{r}$ 1965). Further findings of fish parasites were reported by $R$ a š $i \mathrm{n}(1930,1936)$ from the Moravian catchment area of the Dunaj river. 
Other studies concerning the Dyje river basin appeared later. Dyk and co-workers published a number of reports on parasitic diseases in both pond systems and running waters. The results were included in a review in which they described 134 parasites of fish in the South Moravia area (L u C k y and D y k 1964).

Since 1952 zoological investigation of fish parasites in the southern Moravia rivers were carried out by the workers of the Department of Zoology, Faculty of Sciences, Purkyne University in Brno. Valuable information on parasitic diseases of fish in this region is available ( $\mathrm{V} o j \mathrm{t} k$ et a1. 1954; V o j t k o va 1959; 0 p r a vi $10 \mathrm{vá} 1969$; $\mathrm{P}$ e jč $\circ \mathrm{c} \mathrm{h}$ 1974; E r g e S and L $\circ \mathrm{m}$ 1970).

These zoological publications reflecting basic research on parasitic fauna in fish of the southern Moravia were followed by some of our specialized research projects on the spread of developmental stages of fish flat worms in the State Nature Reserves of southern Moravia ( $\mathrm{L} u$ c $\mathbf{k} \dot{y}$ and $\mathrm{J}$ ir á $\mathbf{s} \mathbf{k} \circ \mathbf{v}$ a 1975) and by investigations into the parasitic diseases of the phytophageous fingerling and their effective prevention ( $\mathrm{u} c \mathrm{k}$ ý et al. 1980).

Apart from infectious and parasitic diseases of $f i s h$, the river basin of Dyje in the area of the future Pálava lakes was also studied in terms of chemical and organic pollution. These risk factors were first recognized by $\mathrm{H}$ e $\mathrm{t}$ e s $\mathrm{a}$ and $\mathrm{S} u \mathrm{k} O \mathrm{p}$ (1982) in a paper on the relation of oxygen availability to fish production in the Mušov lake. The authors described an episode of mass death in fish that occurred in January 1984 (H e $t$ e š a and $S \mathrm{u} \circ \mathrm{p}$ 1985). They reported that at a decrease in water flow to $2 \mathrm{~m}^{3} \cdot \mathrm{sec}^{-1}$, an increase in retention time at an elevated water level for 50 days, and freezing of the surface, the oxygen content dropped to zero and the fish began to suffocate. A first estimate of 80 tons of dead fish worth 1 million crowns reached 250 tons in the final assessment of the disaster.

$\mathrm{H}$ e $\mathrm{t} e \mathrm{~s} \mathrm{a}$ and $\mathrm{s} u k \circ \mathrm{p}$ (1985), who followed oxygen balance in the Mušov lake for several years, concluded that oxygen conditions of the whole reservoir were subject to progressive deterioration. This was demonstrated by comparing the mean values of oxygen dissolved in the water over a two-year period. The following values were found along the lake:

$\begin{array}{lcc} & 1983 & 1984 \\ \text { Drnholec } & 3,91 \mathrm{mg} \cdot 1^{-1} & 1,21 \mathrm{mg} \cdot 1^{-1} \\ \text { Brod nad Dyji } & 4,68 \mathrm{mg} \cdot 1^{-1} & 1.15 \mathrm{mg} \cdot 1^{-1} \\ \text { water gate } & 10,55 \mathrm{mg} \cdot 1^{-1} & 5.65 \mathrm{mg} \cdot 1^{-1}\end{array}$

Materials and Methods

Material for investigation was obtained using electric shocking gears, drop or trawling nets, or, occasionally, by angling or collecting cadavers. Some sampling was done in co-operation with the workers of the Institute of Vertebrate Zoology, Czechoslovak Academy of Sciences Brno, the State Fishery Office in Pohorelice, and the Department of Fisheries and Biosphere Protection of Agricultural Sciences in Brno. in Brno. 
After catching, each fish was thoroughly examined and all pathological conditions were recorded.

Samples of fish were placed in a container with airing facilities and transferred to the laboratory. The numbers of commercial fish examined in 1981 to 1984 are given in Table 1:

Table 1

\begin{tabular}{lrrrrr}
\hline \multicolumn{1}{c}{ Fish species } & \multicolumn{2}{c}{ Number of fish } & Total \\
& -1981 & 1982 & 1983 & 1984 & \\
Esox lucius & 15 & 1 & 1 & 1 & 18 \\
Ctenopharyngodon idella & 4 & 3 & - & 3 & 10 \\
Tinca tinca & - & 2 & 1 & - & 3 \\
Cyprinus carpio & 1 & - & 25 & 13 & 39 \\
Stizostedion lucioperca & 3 & - & 2 & - & 5 \\
Rutilus rutilus & 9 & 20 & 19 & 7 & 57 \\
Leuciscus idus & 2 & - & - & 1 & 3 \\
Scardinius erythrophthalmus & 1 & 15 & 4 & 2 & 22 \\
Alburnus alburnus & - & 3 & - & 3 & 6 \\
Blicca bjoerkna & 6 & 29 & 10 & 7 & 52 \\
Abramis brama & 5 & 3 & 19 & 2 & 29 \\
Carassius carassius & 2 & 2 & 1 & - & 5 \\
Perca fluviatilis & 111 & 24 & 8 & - & 136 \\
Gymnocephalus cernua & - & 3 & 10 & - & 13 \\
\hline & & & & \\
\hline
\end{tabular}

The diagnosis of infectious diseases and the determination of parasites were based on the studies by $\mathrm{B} \mathrm{y} \mathrm{c} \mathrm{h} \circ \mathbf{v ~ s ~ k ~} \mathrm{i}$ j et al. (1962), D y k (1961),.. E r g e s and L o m (1970), L u c k y (1978, 1982) and S c h ä p r c 1 a u s et al. (1979).

Invasion extensity was expressed as follows: $\frac{\text { no. of fish examined }}{\text { no. of fish infected }}$. If more than 10 pieces of fish of the same species were examined, the results were expressed as per cent.

Invasion intensity of protozoa was expressed in terms of maximum and minimum counts seen in the microscope field at magnifications given in the records. From these a mean number of parasites $(\bar{x})$ in one field of view was calculated. Macroscop ic parasites were expressed in actual numbers and a mean value of invasion $(\overline{\mathrm{x}})$ was calculated.

Fish samples were taken at different areas of the Mušov lake. The upper part areas were designated as Locality I (with heavy organic pollution), the lower part areas were named Locality II (with minimum organic pollution) - see Fig. 2. 


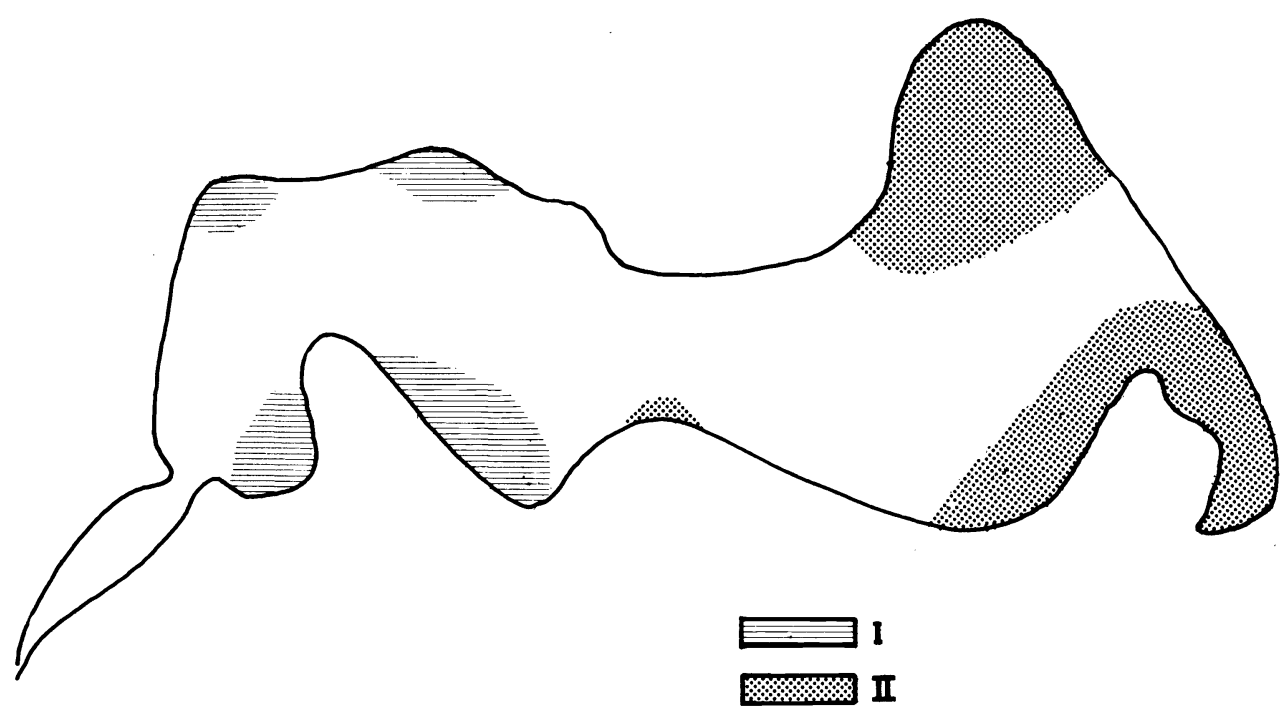

Fig. 2. The Mušov lake with indicated loċalities I. and II.

The degree of pathogenicity of each disease or parasite was scored as: 0 - no pathological changes (usually at a very low invasion intensity)

1 - local changes in the organ (usually at the site of parasite attachment)

2 - mild damage to the organ affected

3 - advanced damage to the organ affected

4 - mild deterioration of the overall health status

5 - severe deterioration of the overall health status

The method of carp stock treatment was based on our earlier experience.

Antiparasitic baths were performed in 10-1itre glass aquariums. Two stock carp, mean body mass $350 \mathrm{~g}$, were placed in each. The experiments were carried out with carp collected during the stocking of the Mušov lake. The bath contained tap water, previously allowed to stand, with enough oxygen produced by an electric aerator and had a temperature of 13 do $15{ }^{\circ} \mathrm{C}$.

Chemical agents used were:

1. Malachite green B (oxalic compound), $7 \mathrm{mg}$ per litre of water

2. Formaldehyde, $50 \%$ solution, $0.25 \mathrm{ml}$ per litre of water

3. Copper sulphate, $3 \mathrm{mg}$ per litre of water

4. Sodium chloride, $20 \mathrm{~g}$ per litre of water

5. Sodium chloride, $10 \mathrm{~g}$ per litre of water

6. A mixture of malachite green and $40 \%$ formaldehyde, $0.5 \mathrm{~g}$ and $0.25 \mathrm{ml}$, respectively, per litre of water

7. Methylene blue, $2 \mathrm{~g}$ per litre of water 
In all experiments the fish were exposed to a bath solution for $1 \mathrm{~h}$ : They were then transferred to a mild flow of fresh water with aeration for $2 \mathrm{~h}$ and killed. The skin and gills were examined for parasites.

\section{Results and Discussion}

A comprenensive survey of the health status of fish was carried out in 1981 to 1983. In January 1984 the majority of fish died due to the lack of oxygen, which made investigations in the following years $(1984,1985)$ rather difficult owing to very low numbers of fish in the lake. Fish for examination were obtained only occasionally and in small samples.

The part of Dyje from Drnholec to Mušov had had a high degree of pollution with organic matter before the lake was built. This repeatedly caused a severe reduction in fish populations. After each such episode, the river was restocked and also naturally colonized with fish from lower parts of the river. The low density of fish population was repeatedly confirmed by the workers of the Institute of Vertebrate Zoology, Brno, who regularly took samples from these parts.

When the Mušov lake was built, water filling the reservoir covered an area with a dense overgrowth of grass and bushy vegetation. Due to this fact the water had very low levels of oxygen, particularly during periods when oxygen was not supplied by green algae.

The upper part of the lake between Drrnholec and Brod nad Dyjí occasionally received large amounts of organic matter brought in by the Dyje river from agricultural and industrial plants. This often produced oxygen deficiency resulting in suffocation and, later, mass death of fish. Oxygen content was regularly checked by the group of hydrobiologists and water management officers.

Permanent pollution of water in the upper lake (Drnholec - Brod nad Dyji) made the area unsuitable for fish with high demands for oxygen. The part between Brod nad Dyjí and Pasohlávky had less contamination and the part between Pasohlávky and the dam had satisfactory oxygen saturation for most of the year.

In accordance with these findings the Brod nad DyjiPasohlávky area was classified as Locality I and the lower 
lake as Locality II. It was not possible to record all episodes of fish death occurring in the lake areas because they happened suddenly, sometimes one following another, and after the death of most fish they could be detected only by chemical analysis of water and determination of dissolved oxygen.

The most severe loss was suffered in the winter period of 1983-84 when during January 1984 the majority of fish died due to suffocation, including the fish with low oxygen demands (carp and tench).

Oxygen content increased again in the summer period due to the action of green algae. The fish grew in number after restocking with carp and due to migration of other species from the middle lake.

The next severe and long winter, during which the lake was covered with a thick layer of ice and snow, resulted again in oxygen depletion followed by suffocation and mass death of fish under the frozen surface. In spring 1985 the lake was again devoid of fish stocks. Oxygen depletion in winter months (leading to suffocation and death of fish) is at present a serious obstacle to utilizing the Mušov lake for fish production and breeding.

Health Status of Esox lucius

The results of examination are presented in Table 2 . Some of the dead pikes collected on rounds in the spring 1981 had flat skin erosions characteristic of erythrodermatitis, although mass death of pikes due to this condition was not recorded in the course of investigation. Nor had any of 30 pikes caught by Ing. Lusk any signs of erythrodermatitis. Skin saprolegniosis was seen in pikes usually in spring months and resulted in decreased resistance of the fish affected. Its occurrence in spring was rather high. Nephromycosis was observed occasionally in older pikes without the presence of marked pathological changes. It usually appeared as small enveloped foci of short fungal filaments.

Eight parasite species were isolated, namely, 4 species of protozoa, a metacercaria, a migrating cercaria, a leech and Acanthocephalus. Locality I had 3 parasite species, Locality II showed 6 parasite species and 3 infectious diseases. The parasitic infections were mild and only Acanthocephalus lucii and Piscicola geometra produced local inflammatory response in the organs affected. 


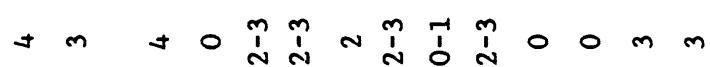

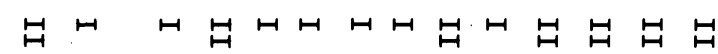

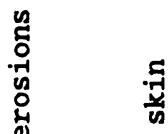

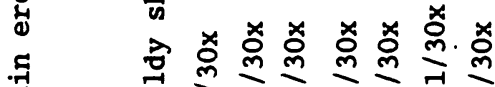

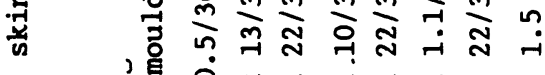

n

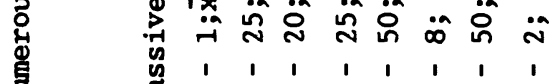

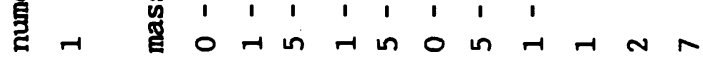

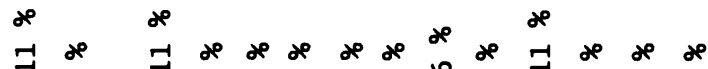

न

1 1 "

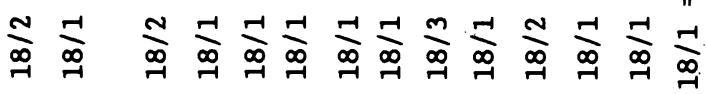

N

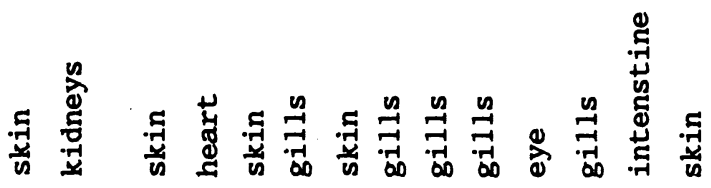

తే

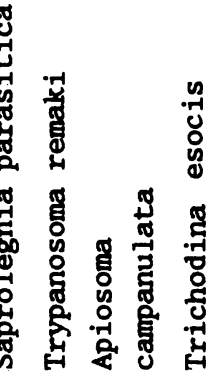

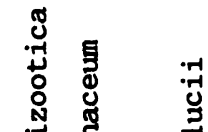
若

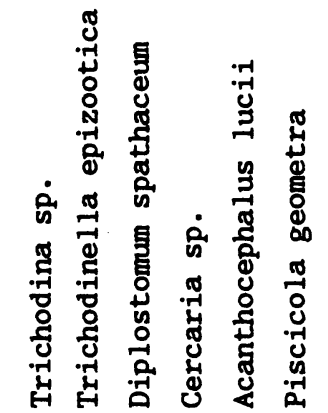


lake as Locality II. It was not possible to record all episodes of fish death occurring in the lake areas because they happened suddenly, sometimes one following another, and after the death of most fish they could be detected only by chemical analysis of water and determination of dissolved oxygen.

The most severe loss was suffered in the winter period of 1983-84 when during January 1984 the majority of fish died due to suffocation, including the fish with low oxygen demands (carp and tench).

Oxygen content increased again in the summer period due to the action of green algae. The fish grew in number after restocking with carp and due to migration of other species from the middle lake.

The next severe and long winter, during which the lake was covered with a thick layer of ice and snow, resulted again in oxygen depletion followed by suffocation and mass death of fish under the frozen surface. In spring 1985 the lake was again devoid of fish stocks. Oxygen depletion in winter months (leading to suffocation and death of fish) is at present a serious obstacle to utilizing the Mušov lake for fish production and breeding.

Health Status of Esox lucius

The results of examination are presented in Table 2. Some of the dead pikes collected on rounds in the spring 1981 had flat skin erosions characteristic of erythrodermatitis, although mass death of pikes due to this condition was not recorded in the course of investigation. Nor had any of 30 pikes caught by Ing. Lusk any signs of erythrodermatitis. Skin saprolegniosis was seen in pikes usually in spring months and resulted in decreased resistance of the fish affected. Its occurrence in spring was rather high. Nephromycosis was observed occasionally in older pikes without the presence of marked pathological changes. It usually appeared as small enveloped foci of short fungal filaments.

Eight parasite species were isolated, namely, 4 species of protozoa, a metacercaria, a migrating cercaria, a leech and Acanthocephalus. Locality I had 3 parasite species, Locality II showed 6 parasite species and 3 infectious diseases. The parasitic infections were mild and only Acanthocephalus lucii and Piscicola geometra produced local inflammatory response in the organs affected. 


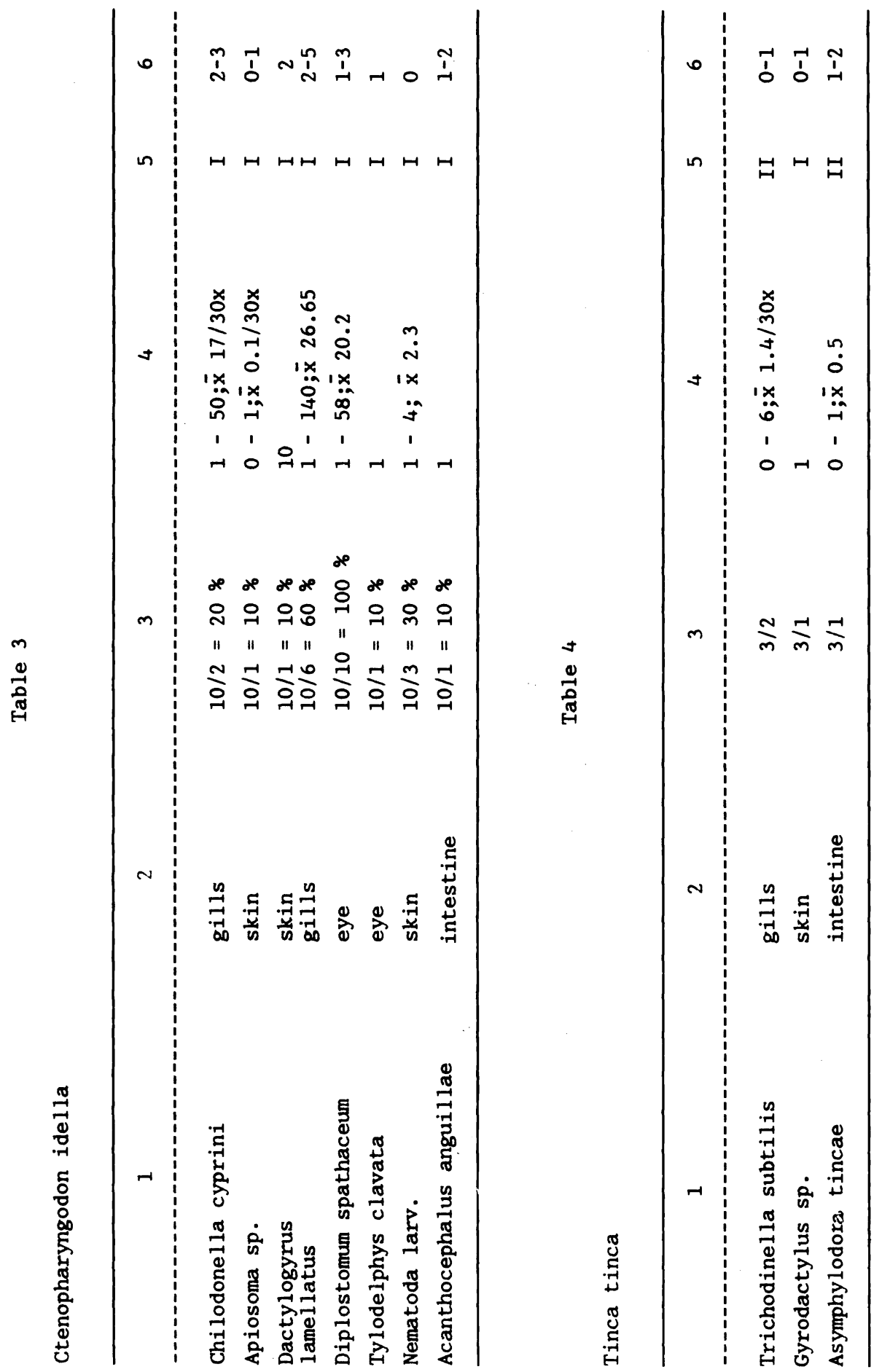


The health status of pikes in the lake developed satisfactorily and the fish caught showed good nutritional status and health.

Health Status of Ctenopharyngodon idella

The results of examination are shown in Table 3 and in the department record of May 6, 1982. The latter includes pathological and anatomical findings and the results of microbiological examination confirming the presence of erythrodermatitis in 2- to 3-year-old fish. This condition resulted in the death of several tens of fish in drainage canals near Brod nad Dyjí. The dead fish had Dactylogyrus lamellatus on gills and large amounts of Diplostomum spathaceum metacercariae in the lenses.

From the material, 7 parasite species were isolated: 2 protozoan species, a monogenea, metacercariae of 2 species, some nematoda larvae and Acanthocephalus anguillae.

Erythrodermatitis and all of the parasites were found in Locality I. No white amur was obtained for examination from Locality II.

The parasite species producing most severe pathological conditions were: Chilodonella cyprini, Dactylogyrus lamellatus and Diplostomum spathaceum. Chilodonellosis was diagnosed early in spring and was involved in marked deterioration of fish $s$ health; dactylogyrosis appeared in summer. It was repeatedly confirmed that the white amur is highly susceptible to diplostomosis, as already reported by $\mathrm{L} u$ c $k \dot{y}$ (1981). The massive infestation with these parasites can have an adverse effect on the health status of the fish stock.

Health Status of Tinca tinca

The results of examination are presented in Table 4. Only 3 types of parasitic diseases were diagnosed in the tench. Their aetiological agents were: Trichodinella, Gyrodactylus and a trematode. Both localities had 2 parasite species each.

To obtain a large sample of tenches was very difficult. The number of fish available for examination ranged only from 10 to 15. All were in good health and their organs had normal appearances. The parasites were isolated in very low numbers. 
$\stackrel{m}{1}-\stackrel{m}{1} m m N N$ N

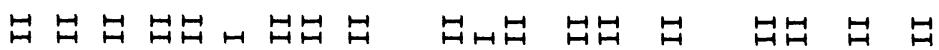

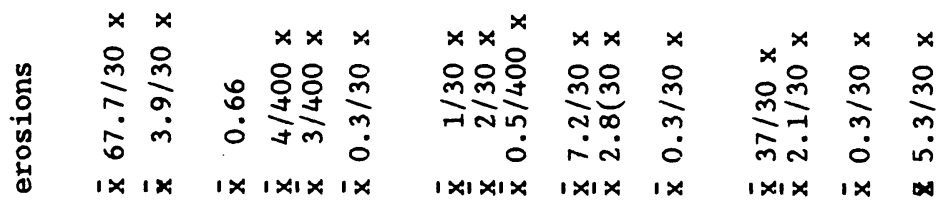

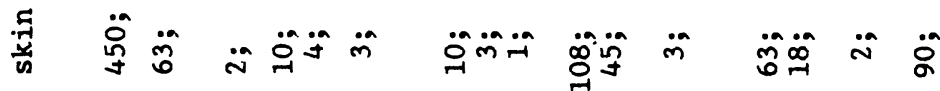

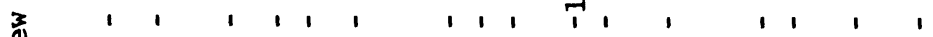
$\Psi$ H

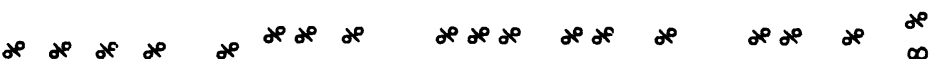
ำ ก " I "

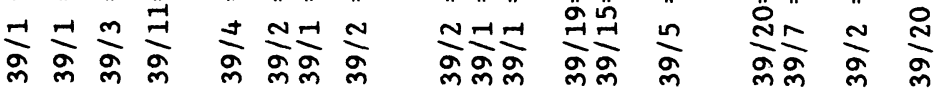

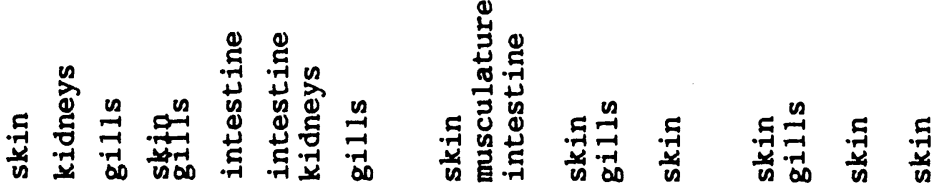

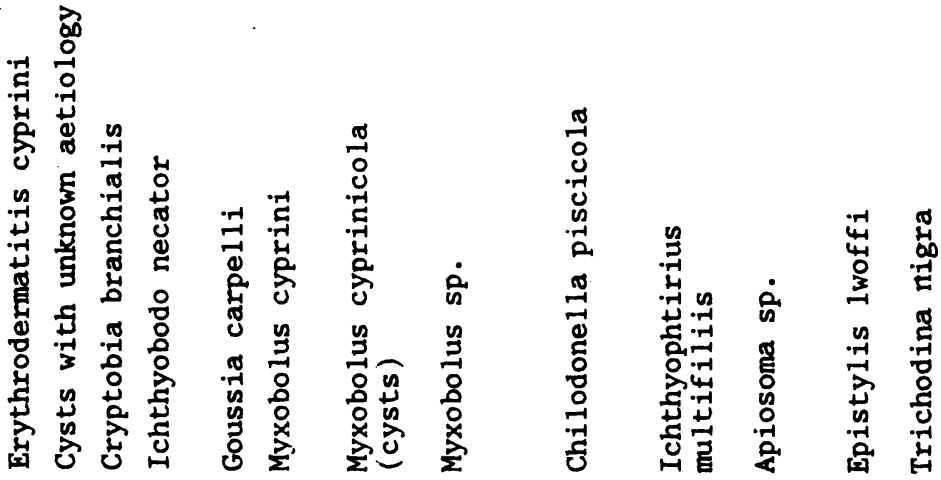




$$
\text { サロ }
$$

.

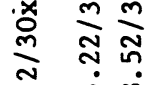

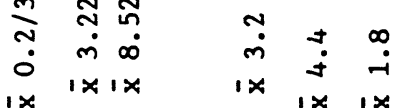

$\ddot{m} \ddot{n} \ddot{g} \quad \ddot{m} \ddot{n} \ddot{j}$

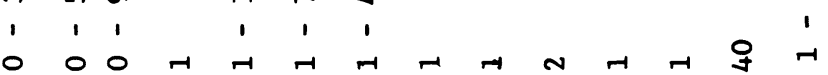

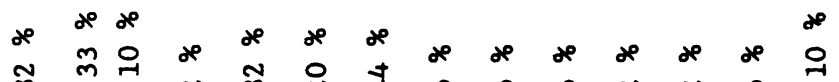

ஸ்

"1 "I"

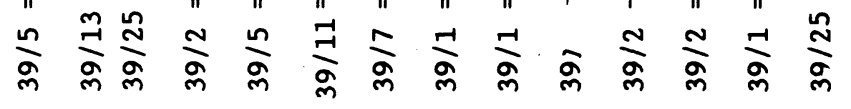

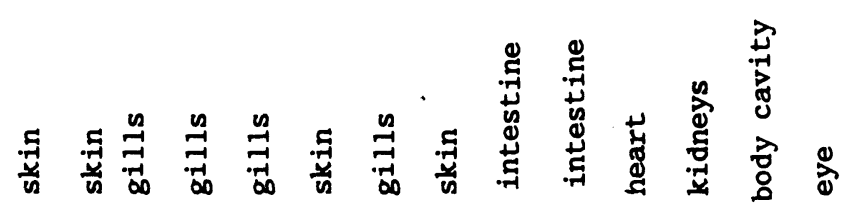

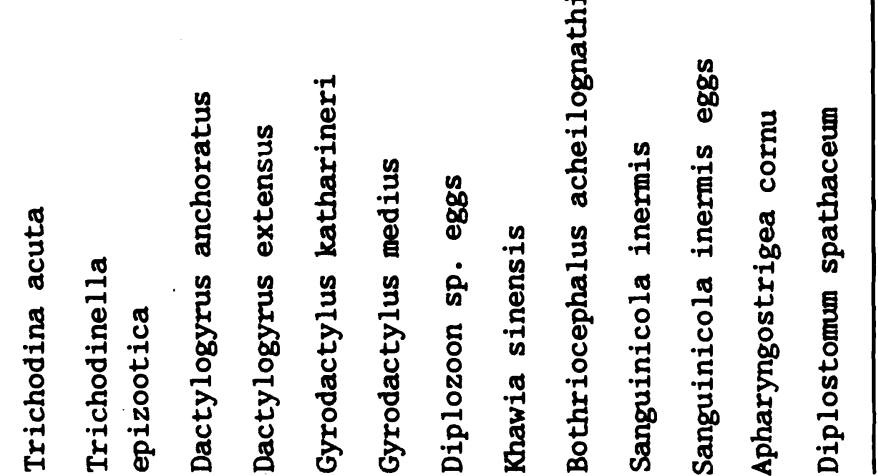

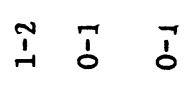

$\forall \forall \quad$

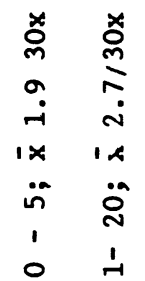

ㄱำ

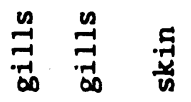

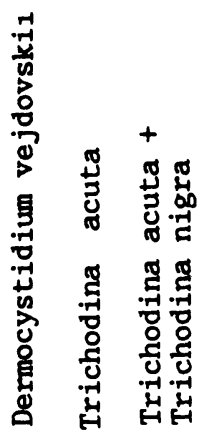




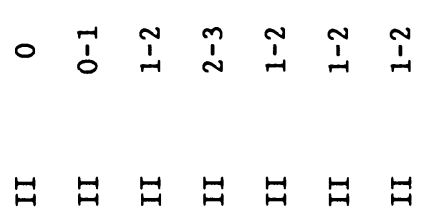

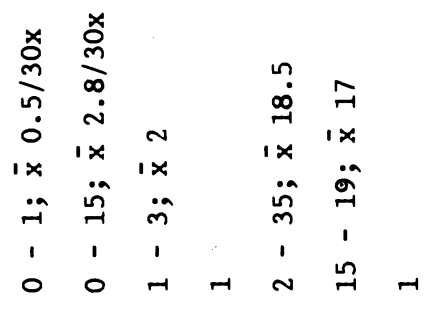

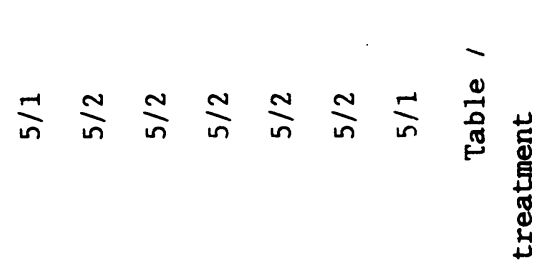

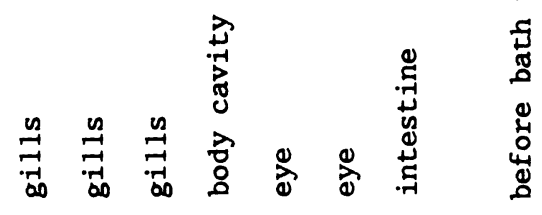

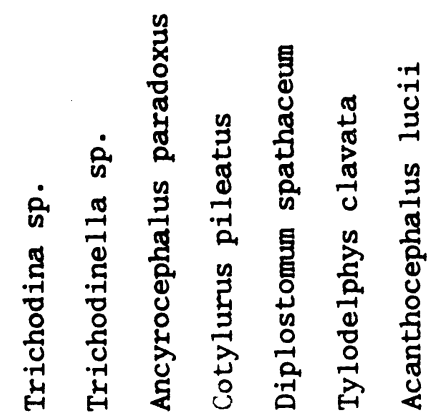

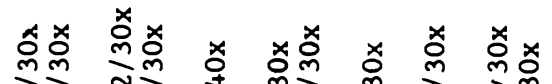

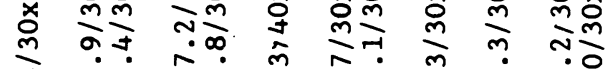

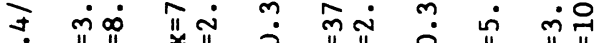

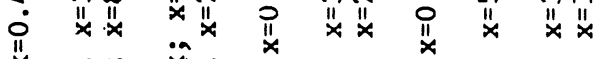
艾 $\ddot{x} \ddot{\bar{x}} \ddot{\tilde{x}}$ o

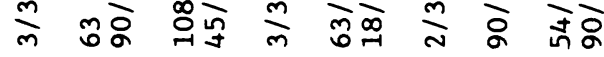

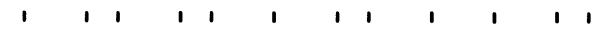
00000000000

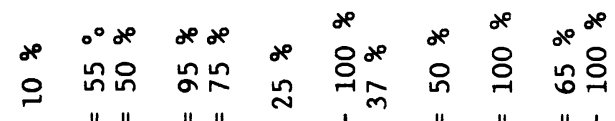
"

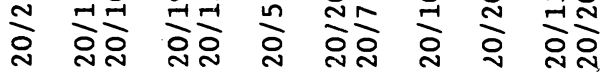
劣

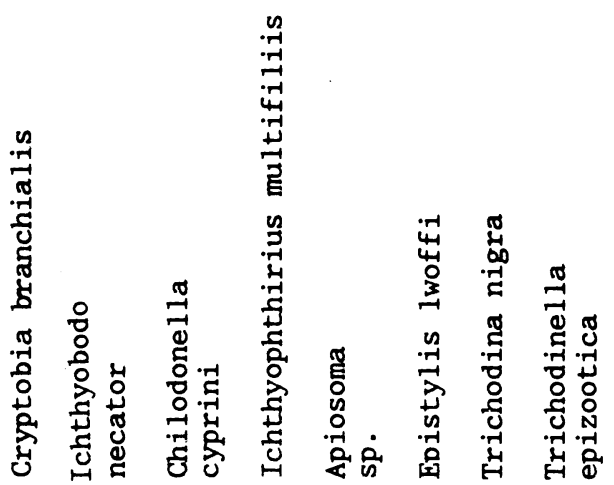




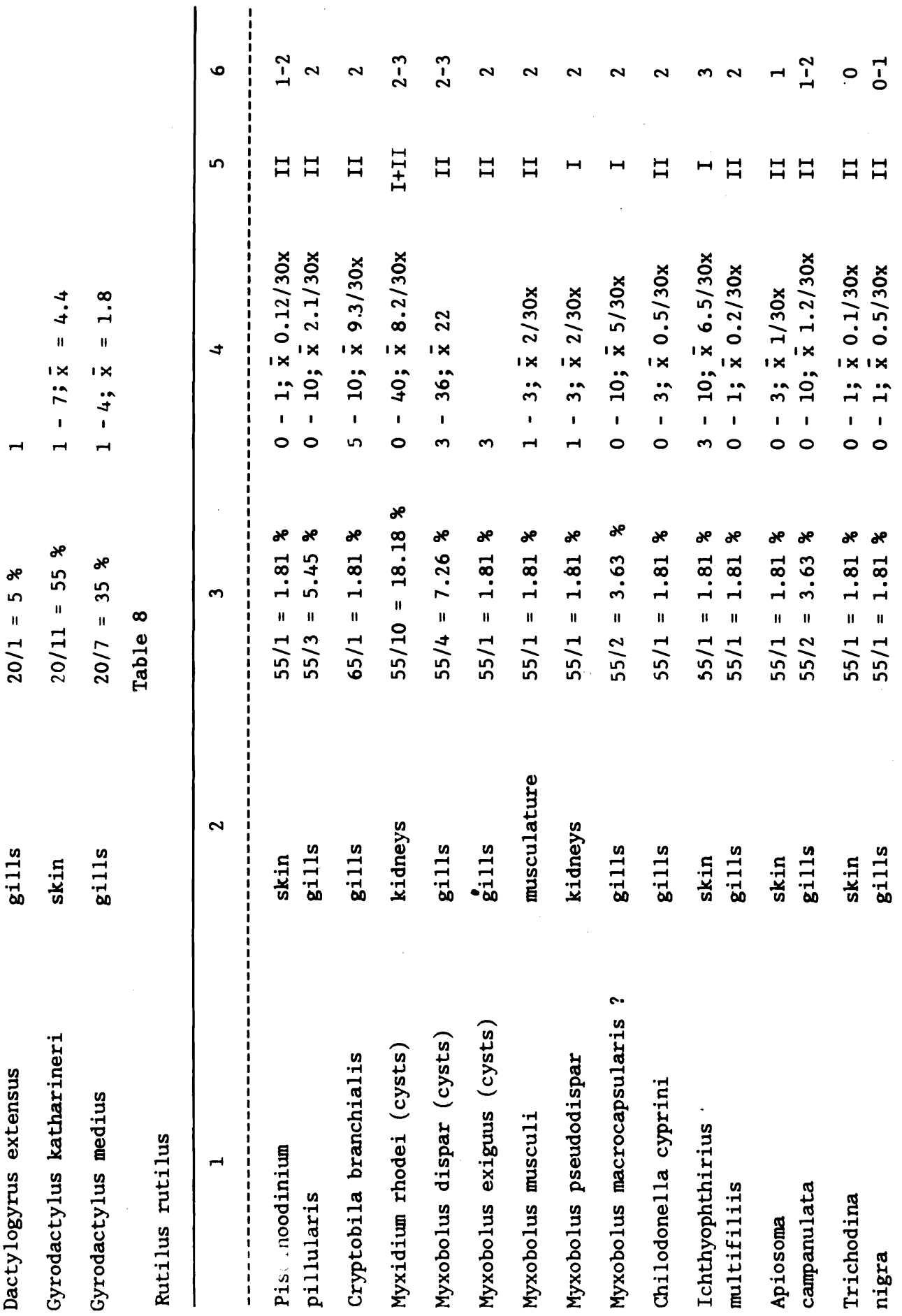




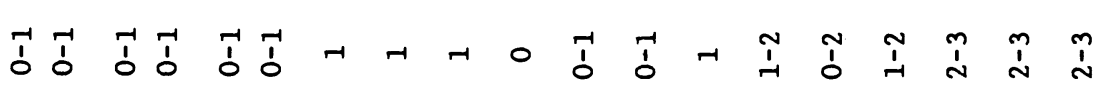

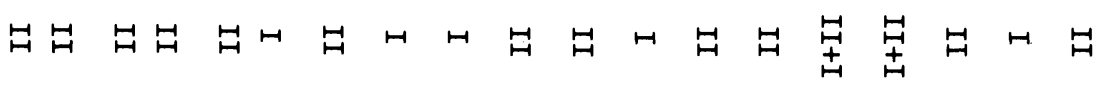

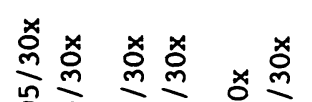

$\begin{array}{llll} & \\ & & \\ 0\end{array}$

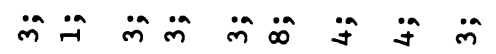

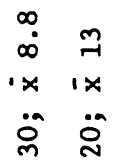

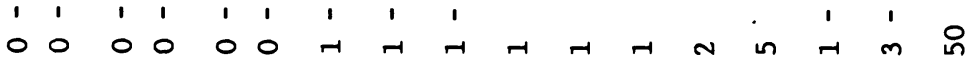

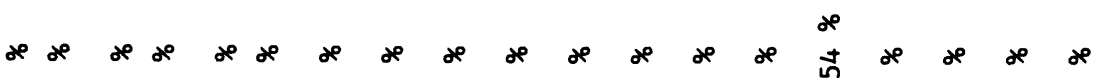

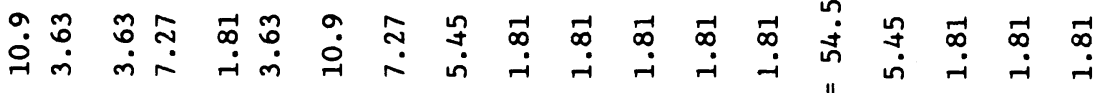

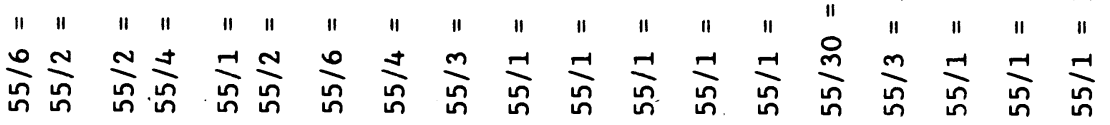

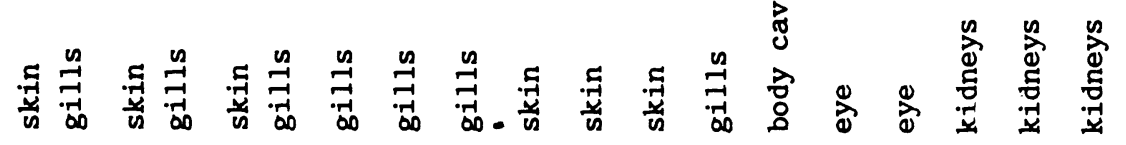

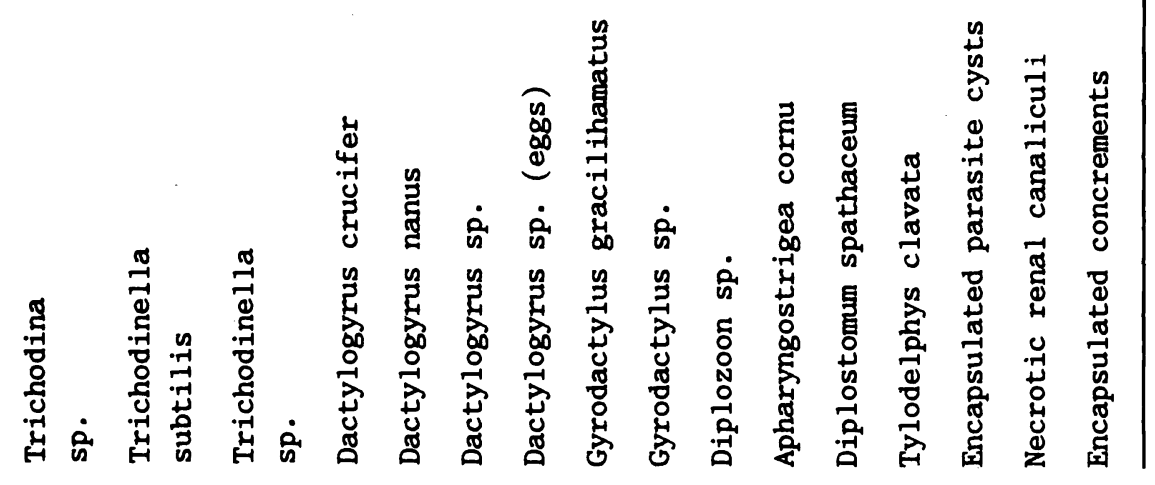


Health Status of Cyprinus carpio

The results of examination are shown in Table 5. Erythrodermatitis was diagnosed only in one case but inflammatory skin lesions were often detected when observing fish in the lake. These were stock carp transferred to the lake from a near rearing pond. An outbreak of erythrodermatitis of an extent known to occur in carp rearing ponds was not recorded.

On parasitological examination 23 species were found: 13 protozoa, monogeneas of 5 species, 2 tapeworm species, a trematode and metacercariae of 2 species. Most pathologanic appeared to be: Cryptobia branchialis, Chilodonella cyprini, Dactylogyrus extensus, Khawia sinensis and Bothriocephalus acheilognathi. The largest dissemination was recorded with Chilodonella cyprini in spring.

Locality I contained 5 and Locality II had 25 parasite species. To obtain a large sample straight from the lake was very difficult.

The highest infestation was recorded in stock carps after they were transferred from storage ponds to the lake. The total infestation in the lake, however, was low. Most of the samples were collected from Locality II.

Health Status of Stizostedion lucioperca

Table 6 shows the results of examinations. Glasseyed-pikes got rarely caught in nets. From 10 parasite species 5 were protozoa, 1 monogenea, 3 metacercariae and 1 Acanthocephalus. All glasseyed-pikes came from Locality II so that our parasite findings were placed in this locality, too.

Pathological changes appeared as minor foci on gills, characteristic of dermocystidiosis; severe lesions were caused by eye metacercariae found in large numbers. Acanthocephalus lucii produced local inflammation in intestinal mucosae.

The overall health status of glasseyed-pikes was considered satisfactory.

Health Status of $\underline{\text { Rutilus }}$ rutilus

The results of examination are in Table 8 . The examination revealed only parasitic diseases and pathological lesions of chronic nature in the kidney. 


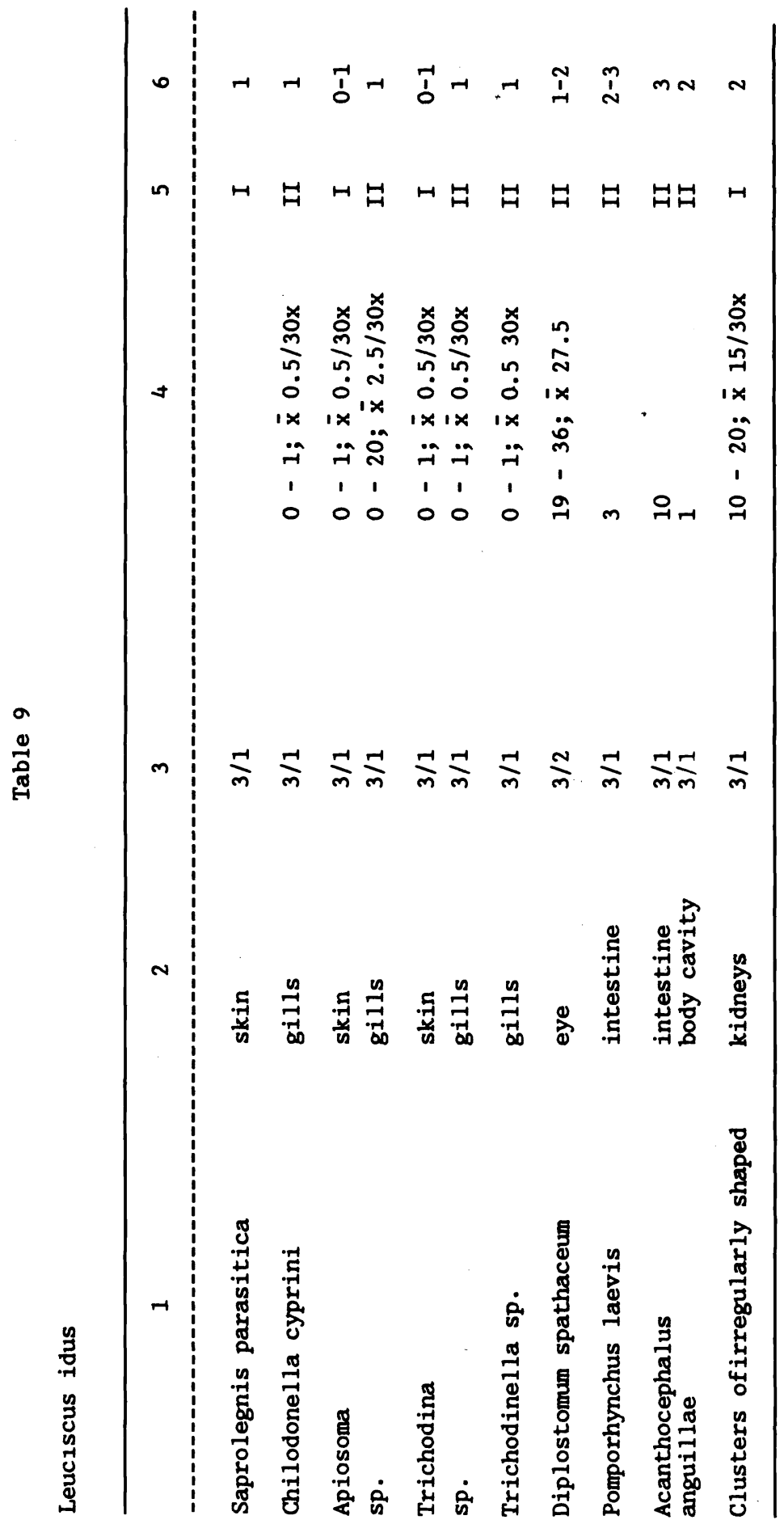


From roaches, 24 species of parasites were isolated: 15 protozoa, monogeneas of 6 species and metacercariae of 3 species. Pathological conditions were produced by protozoa of the genera Myxidium and Myxobolus manifested as marked changes in the kidneys and on gills. Monogenea were recorded only sporadically. Out of the metacercariae detected only Diplostomum and Tylodelphys were frequently found in roaches'eyes.

The health status of roaches in both localities was regarded as satisfactory.

Health Status of Leuciscus idus

The results of examination are given in Table 9. The occurrence of ides in catching nets was only occasional. Thus the number of the fish available for examination was low.

The only infectious disease found was a mild infestation of the skin due to Saprolegnia.

The parasitic diseases diagnosed were caused by 7 species, namely, 4 protozoan species, a metacercaria and 2 Acanthocephalus species. One fungal and 2 parasitic infections were found in Locality I, 7 parasite species were recorded in Locality II.

Acanthocephalus was found to produce inflammatory changes at the site of infection and Diplostomum spathaceum metacercariae were seen in rather high number in the lenses of the fish. The other parasites were present in low numbers.

The health status of the examined fish was regarded as satisfactory; health of the fish with mild Acanthocephalus infestation was less satisfactory.

Health Status of Scardinium erythrophthalmus

The results of examination are shown in Table 10. The excamination revealed only parasitic diseases and occasional enveloped cysts of unknown aetiology in the kidneys.

The parasitic infections were caused by 14 species, namely, 10 protozoa, monogenea of 3 species and 1 metacercaria.

Nine and 11 parasite species were found in Localities I and II, respectively. 


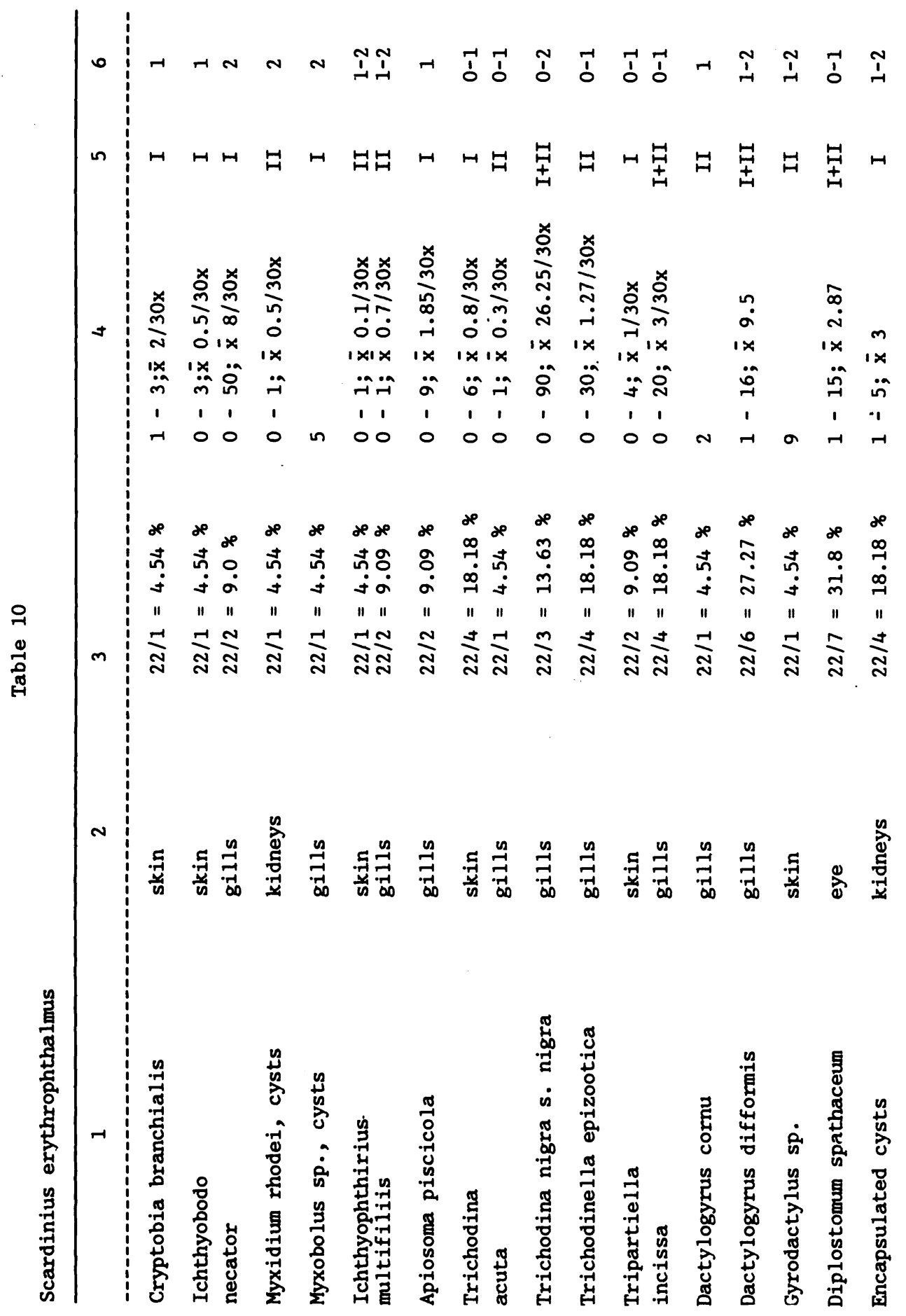


Mild lesions were produced by some species, such as Ichthyobodo necator and by Trichodina nigra and Dactylogyrus difformis in spring.

Infestation of the rotengle with parasites was usually mild so that the fish could be regarded as being in good health.

Health Status of Alburnus alburnus

The results of examination are shown in Table 11. For examination only 3 pieces of fish were obtained.

Only 2 protozoan species were isolated in very low numbers. They were found in Locality $I$.

The health status of the fish examined was good.

Health Status of Blicca bjoerkna

The results of examination are presented in Table 12 . Nephromycosis and enveloped foci in the kidney were diagnosed in silver breams repeatedly. The parasitic infection was manifested as massive occurrence of fungal foci, with resulting impairment of renal function.

From the fish, 33 species of parasites were isolated, some of were determined only at the genus level. Among protozoa, 13 species were distinguished, monogenea were of 11 species, tapeworms and round worms were of 2 species each, plerocercoids of one species and metacercariae of 3 trematode species were determined. Also nematode and mollusc larvae were detected.

Locality' I was characterized by 22 parasite species, Locality II by 21 parasite species. Pathological conditions were produced by Eimeria sp., Myxidium rhodei and Myxobolus oviformis protozoa and the tapeworms. Also all metacercarias were involved producing massive infestations of fish eyes. The number of affected fish, however, was not high.

The health status of silver breams was considered satisfactory except for that of the fish massively infested with parasites or affected by nephromycosis. 


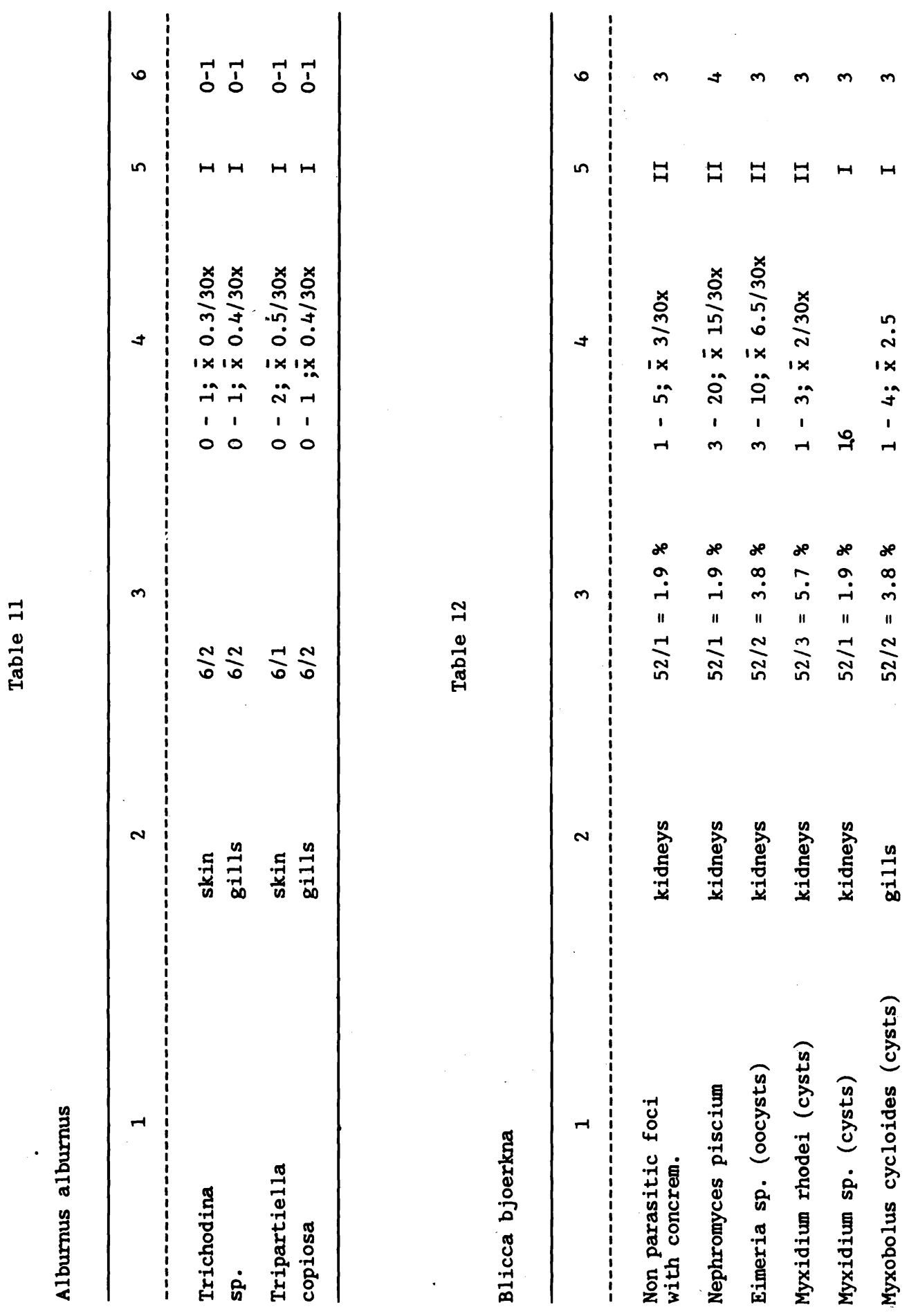




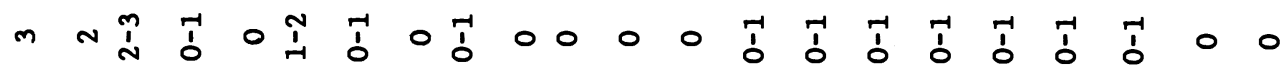

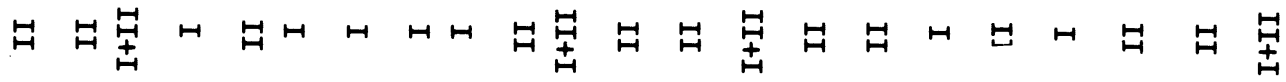

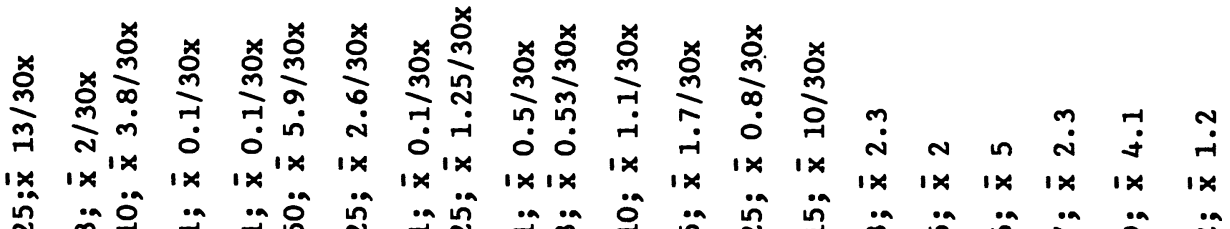

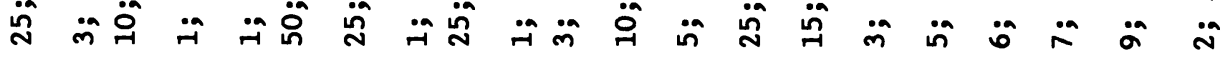
-1
A

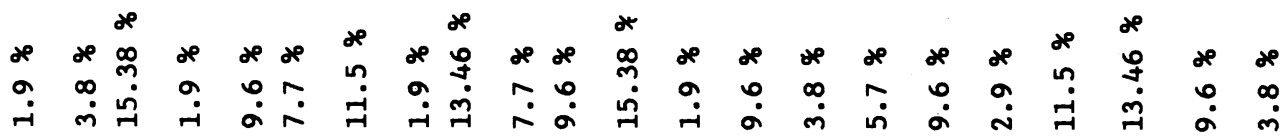
" I II II I "

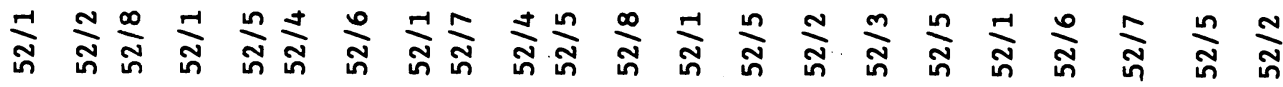

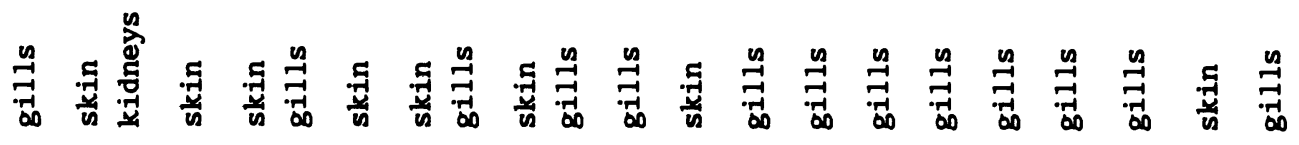
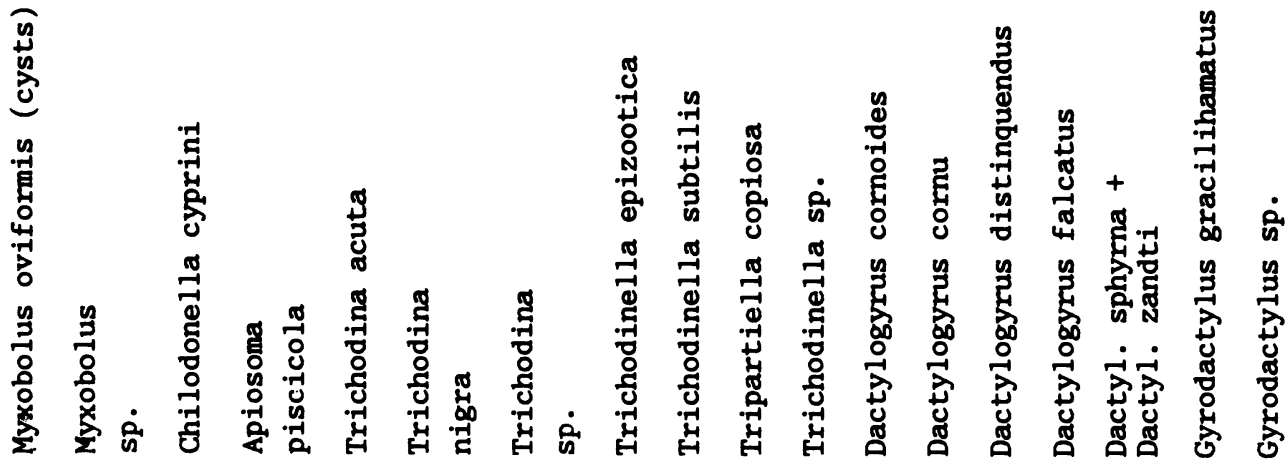


$$
\begin{aligned}
& \text { ṫ } \\
& \text { 吉吕吕 }
\end{aligned}
$$

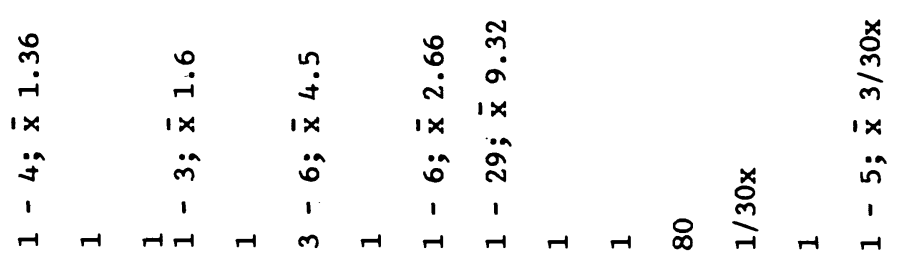

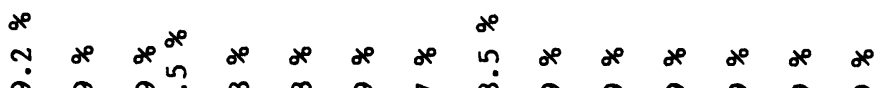

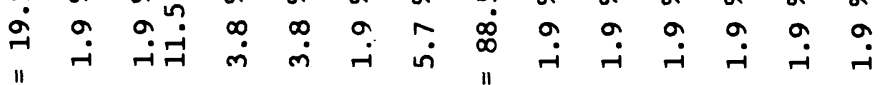
" " " " " " " กิ

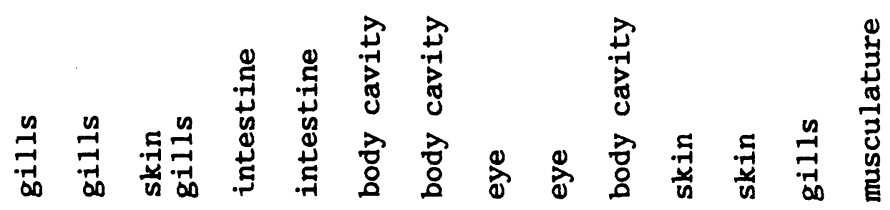

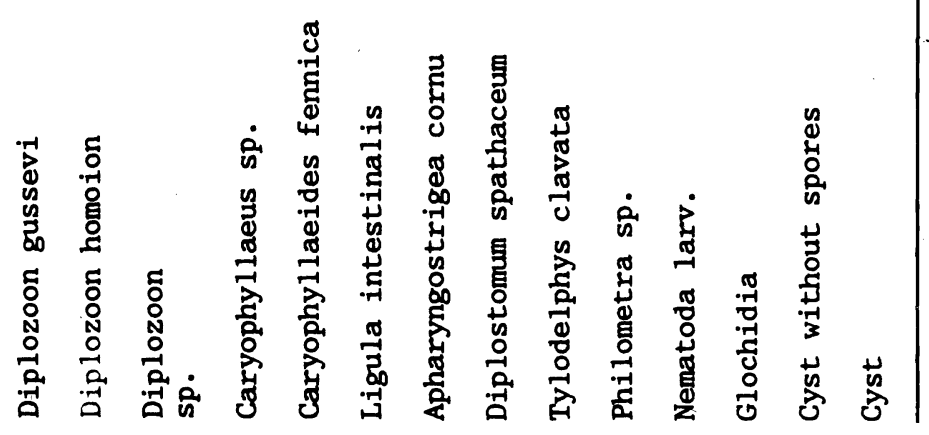


Health Status of Abramis brama

The results of examination are in Table 13. Some fish suffered from saprolegniosis of skin which, however, was of a limited extent and did not produce overt signs of disease.

Aetiological agents of parasitic diseases were 24, out of which 8 were protozoan species, monogenea were of 10 species, 2 were tapeworm species, metacercariae were of 2 trematode species and 2 were arinropod species.

Locality I showed 18 and Locality II 16 parasite species.

The protozoan Myxobolus exiguus, when found in large numbers, markedly reduced the respiratory function of the gills. Some of the monogeneas were also found in great amounts on the gills. Severe infection of the lenses was caused by metacercarias of Diplostomum spathaceum.

Of importance was the finding of Bothriocephalus acheilognathi which presents a serious health hazard to carp fingerlings in large-scale production.

The health status of zobels was regarded as satisfactory. In the fish infested with some of the parasites it was considered less satisfactory.

Health Status of Carassius carassius

The results of examination are in Table 14. Mycobacteriosis was suspected in the kidneys of one of the crucian carps examined since the shape and size of the nodules found there corresponded in structure to this condition. Nodules due to sanguinicolosis had a different appearance. It could not be ruled out, however, that the nodules found were not old nodes containing completely necrotic Sanguinicola eggs.

The parasites were determined as 3 species of protozoa, monogeneas of 1 species, 1 species of trematode, metacercaria and cercaria of 1 species each, e.g., 7 species altogether.

Five species were observed in Locality $I$ and 3 in Locality II: Parasites found in Locality I fish were not seen in Locality II fish except for Diplostomum spathaceum found in both localities. 


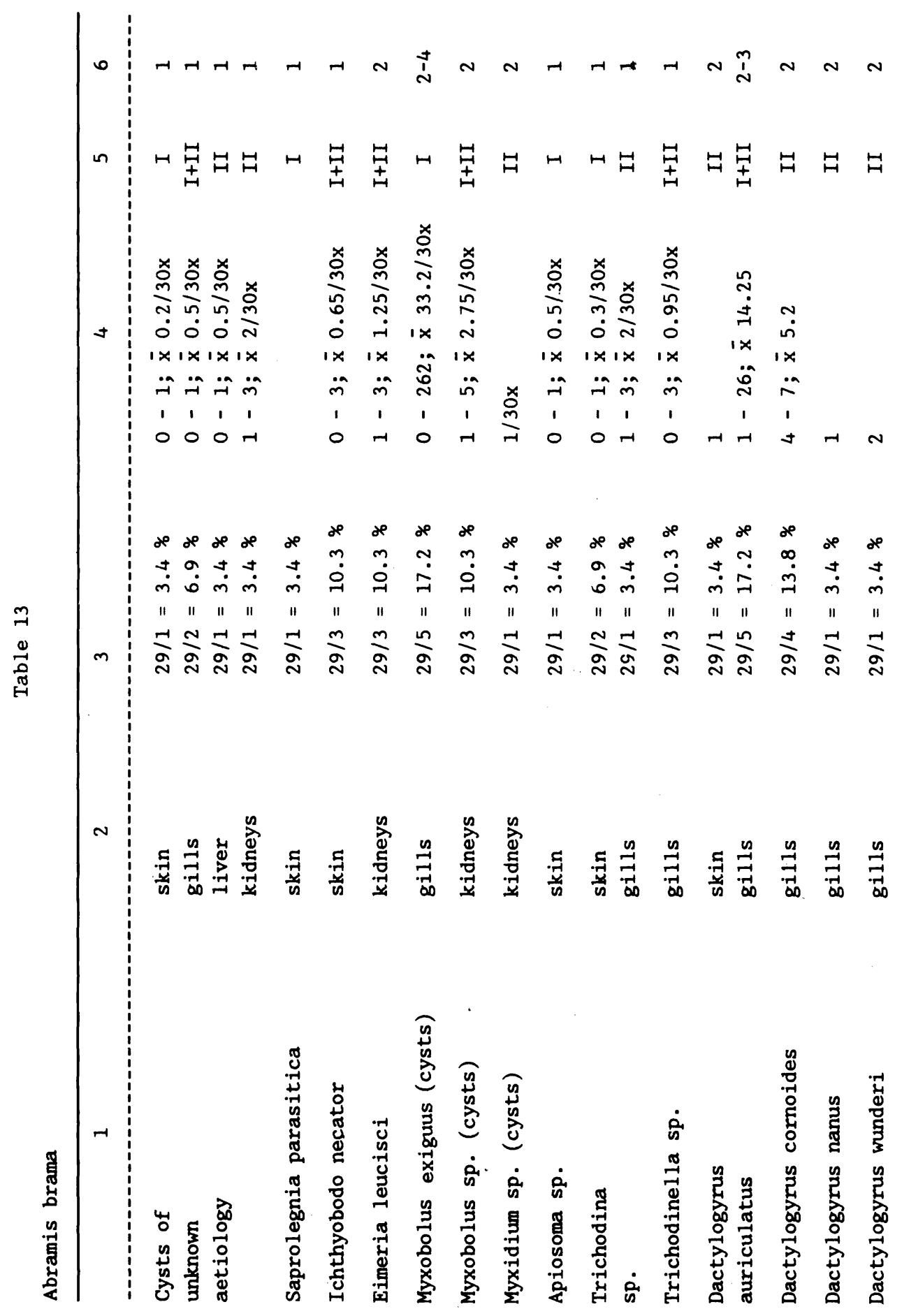




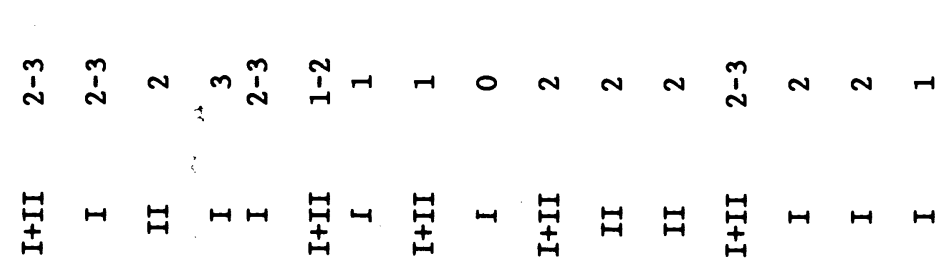

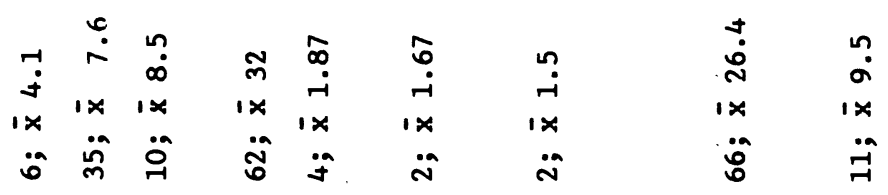

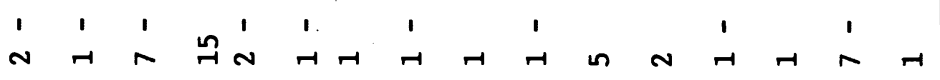

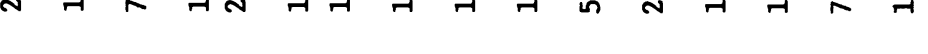

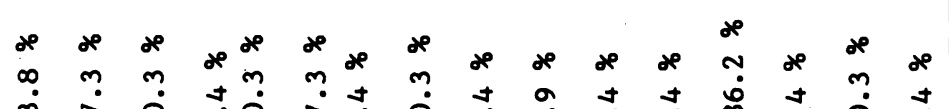

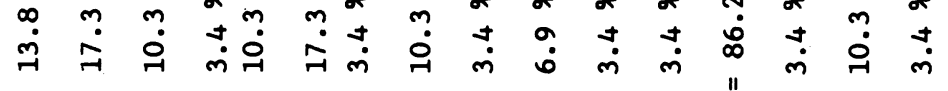
" I " $\mid$ " $\mid$ "

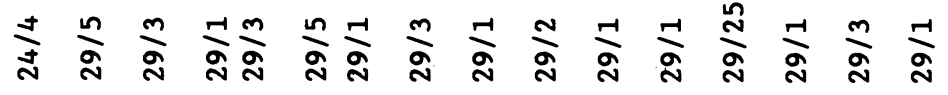

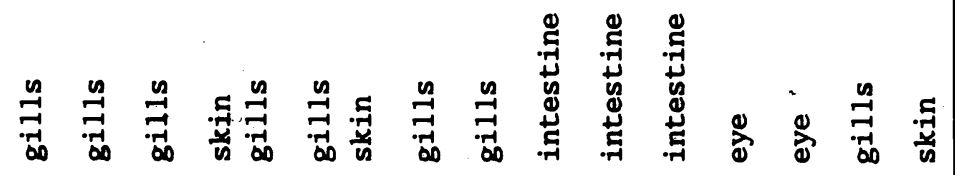

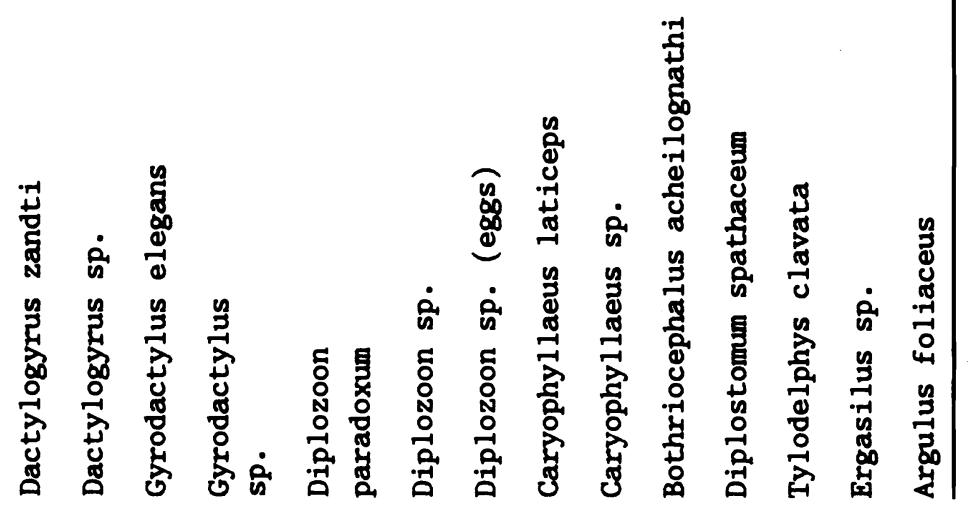




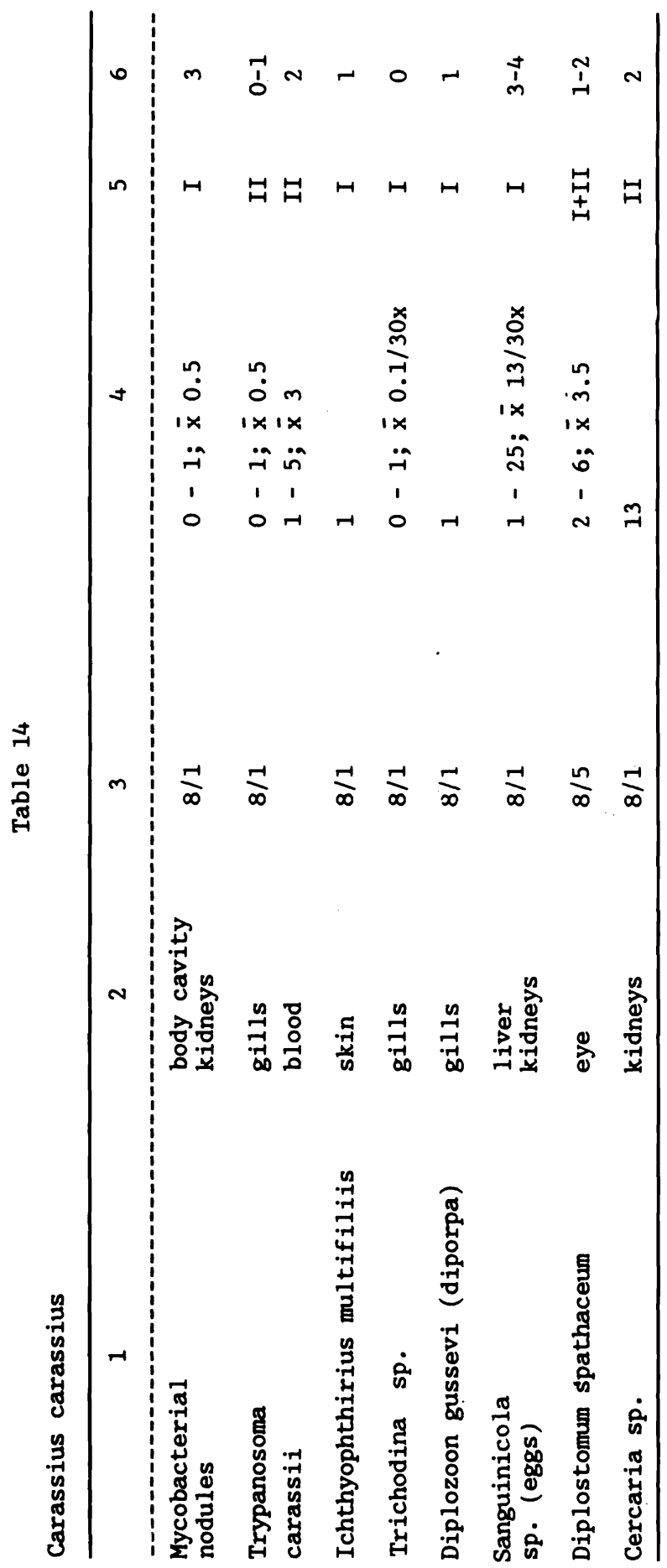


The occurrence of parasites was sporadic with the exception of Sanguinicola eggs which were found in the livers and kidneys, producing a chronic form of sanguinicolosis.

The health status of the crucian carp examined was considered satisfactory but the presence of Sanguinicola organisms remained a potential health hazard.

Health Status of Perca fluviatilis

The results of examination are in Table 15. Branchiomycosis was diagnosed in Locality II in one of the 33 fish examined. Branched fungal filaments with spores found in gills were classified as Brachiomyces sanguinis. The infection of the gills, however, was mild.

Nephromycosis was diagnosed in Locality I. It was manifested as occasional clusters of enveloped foci in the kidneys of some fish.

Parasites isolated were determined as 8 species of protozoa, monogeneas of 1 species, metacercariae of 13 species, 2 Acanthocephalus species and an arthropod and a mite, altogether 17 species.

Eleven and 14 species of parasites, respectively, were recorded in Localities I and II.

When the extensity and the intensity of each parasitic infection were assessed, it could be concluded that the highest degree of extensity was with protozoa, the lowest one with worms. The most pathogenic species were Acanthocephalus lucii, Tylodelphys clavata and Cotylurus pileatus, all producing marked lesions in the organs affected. Only an infrequent occurrence of Triaenophorus nodulosus plerocercoids was recorded in the liver of perches; it was a parasitic infection often seen in this fish species in other localities.

The health status of the fish examined was satisfactory and only in some perches with parasitic or fungal diseases as less satisfactory.

Health Status of Gymnocephalus cernua

The results of examination are listed in Table 16. This fish species was present in the lake only in low numbers. Only a few pieces of fish were obtained for examination from Locality II. 


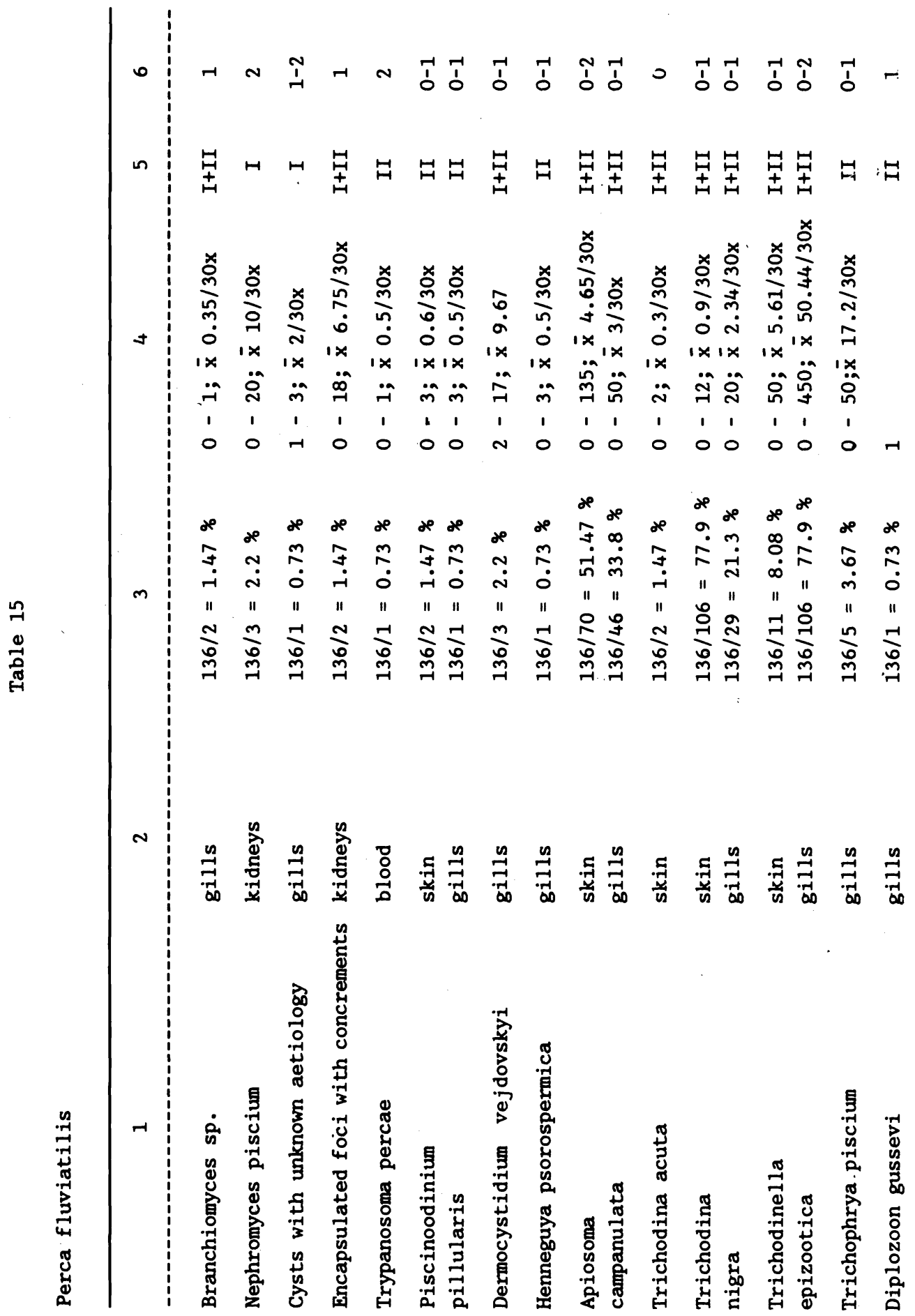




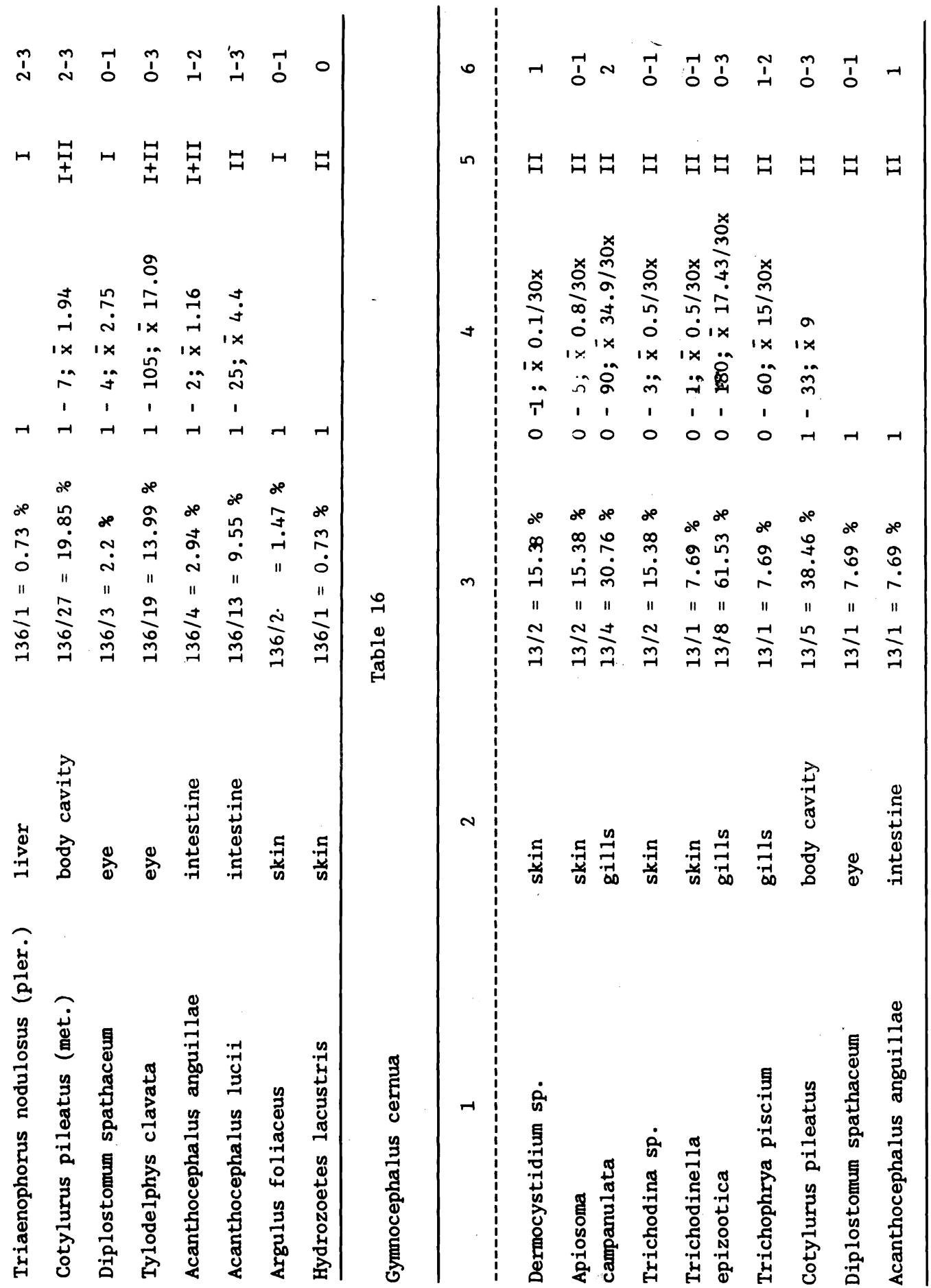


Parasitic diseases were caused by 8 species, namely; 5 protozoan species, metacercariae of 2 species and 1 Acanthocephalus species.

The parasitic infections were usually very mild. More marked infestations were recorded with Trichodinella epizootica and Cotylurus pileatus. These species produced pathological lesions at the sites of multiplication.

The health status of the fish examined was considered satisfactory. Massive infestation with Trichodinella epizootica was regarded as an adverse factor, particularly during a decrease in oxygen content.

The health status of non-commercial fish including their infestation with parasites can be indirectly related to the health of commercial fish since the infected fish can be a source of further parasite spread. Table 17 presents common parasites of the carp (Cyprinus carpio) recorded in the non-commercial fish under study. All of the parasites were also found on carps in the Mušov lake.

In 1983 the stock carps prepared to be placed in the lake were examined for parasites and a large number of different ectoparasites were found on the skin and gills (Table 7). Such infection might markedly weaken the fish stock. To remove these the fish were treated with antiparasitic baths (see Methods) during their transport. After the treatment, examination of the skin and gills for parasites gave the following results:

1) Bath in a solution of malachite green $B$ skin: occasional Chilodonella cyprini with no ciliary movement; gills: no pathogens

2) Bath in a 40\% formaldehyde solution skin: no pathogens

gills: occasional Apiosoma sp. without ciliary movement

3) Bath in a copper sulphat solution

skin: occasional Chilodonella cyprini without ciliary movement;gills: no pathogens.

4) Bath in a $2 \%$ sodium chloride solution

skin: no pathogens

gills: no pathogens 
arasi e

* Cryptobia branchialis

* Ichthyobodo necator

Myxidium rhodei

Myxobolus dispar

Myxobolus macrocapsularis

Myxobolus oviformis

* Chilodonella cyprini

* Ichthyophthirius multifiliis

* Trichodina acuta

* Trichodina nigra

Trichodinella epizootica

Gyrodactylus elegans

Carvophvllaeus laticeps
Rutilus rutilus

Scardinius erythrophtalmus

Scardinius erythrophthalmus Abramis brama

Rutilus rutilus

Scardinius erythrophthalmus

Blicca bjoerkna

Rutilus rutilus

Rutilus rutilus

Blicca bjoerkna

Rutilus rutilus

Leuciscus idus

Blicca bjoerkna

Rutilus rutilus

Scardinius erythrophthalmus

Carassius carassius

Scardinius erythrophthalmus

Blicca bjoerkna

Perca fluviatilis

Rutilus rutilus

Scardinius erythrophthalmus

Blicca bjoerkna

Perca fluviatilis

Scardinius erythrophthalmus

Blicca bjoerkna

Perca fluviatilis

Gymnocephalus cernua

Abramis brama

Abramis brama 
Table 17 - cont.

Parasite

Host

* Diplostomum spathaceum

Rutilus rutilus

Leuciscus idus

Scardinius erythrophthalmus

Blicca bjoerkna

Abramis brama

Carrasius carassius

Perca fluviatilis

Gymnocephalus cernua

Acanthocephalus anguillae

Leuciscus idus

Perca fluviatilis

Gymnocephalus cernua

Acanthocephalus lucii

Pomporhynchus laevis

Argulus foliaceus

Perca fluviatilis

Leuciscus idus

Abramis brama

Perca fluviatilis

cizopasnici zjištěni na kaprech z Mušovské zdrže

5) Bath in a $1 \%$ sodium chloride

skin: occasional Apiosoma sp. without ciliary movement gills: infrequent Ichthyobodo necator; some were moving

6 ) Bath in a solution of malachite green and $40 \%$ formaldehyde

skin: occasional Trichodina sp. and Chilodonella cyprini without ciliary movement

gills: no pathogens

7) Bath in a methylene blue solution

skin: occasional Apiosoma sp. without ciliary movement gills: no pathogens

From this examination it appears that the stock carp is resistant to the concentrations of the solutions used for $1 \mathrm{~h}$ and that all the bath solutions except for $1 \%$ sodium chloride were capable of controlling the presence of protozoa and monogenea on the skin and gills. 


\section{Conclusions}

Several hundreds of fish from the Mušov lake were investigated. They were obtained during routine fish production practices, experimental catches, stocking and restocking of the lake, laboratory examination of dead fish and preventive check-ups. Seventy-five pieces of commercial and 323 pieces of non-commercial fish with more than 40 and more than 80 diseases and pathological conditions, respectively, were recorded. Asphyxia associated with mass death and pathological conditions of unclear aetiology were repeatedly diagnosed in the two groups.

It can be concluded that the health status of the fish species examined was satisfactory and the mild diseases diagnosed did not affect the growth of fish to a great extent. The more serious conditions are discussed in the appropriate sections.

The investigation showed that the lake was contaminated with many infectious agents carried by older fish, particularly carp, used for stocking. A preventive procedure tested in this study included antiparasitic baths applied during the transport of fish from the ponds to the lake.

To prevent fish from dying of suffocation it is necessary to ensure a sufficient supply of water free from organic pollution. For wintering of fish in severe wheather conditions it is recommended that powerful mechanical aerators be developed to maintain sufficient saturation of water with oxygen throughout the lake.

Our results also confirmed the necessity of surveying the health status of non-commercial fish that can become a source of infection for commercial fish.

\section{Zdravotní stav ryb Mušovské zdrže}

Výzkum zdravotního stavu ryb Mušovské zdrže zjistil v letech 1981 - 1985 u hospodářsky cenných druhů (Esox lucius, Ctenopharyngodon idella, Tinca tinca, Cyprinus carpio, Stizostedion lucioperca) 2 infekčni choroby, 40 původicu invazních chorob a několik chorobných stavủ a u hospodár̆sky méně cenných druhů (Rutilus rutilus, Leuciscus 
idus, Scardinius erythrophthalmus, Alburnus alburnus, Blicca bjoerkna, Abramis brama, Carassius carassius, Perca fluviatilis, Gymnocephalus cernua ) 4 infekční choroby, 79 původců invazních chorob a několik chorobných stavů. Soubor zjištěných cizopasníků $u$ hospodářsky cenných druhů ryb nedosahoval počtu zjištěných druhů $v$ dřívějších výzkumech uveřejněných $\mathrm{v}$ pracích citovaných $\mathrm{v}$ literárním přehledu.

Během výzkumu došlo na sledované lokalitě $\mathrm{k}$ několika havariím, způsobeným nedostatkem kyslíku rozpuštěného ve vodě. Největší havárie, které způsobily téměr̆ totální vyhynutí ryb v nádrží, byly zaznamenány v lednu 1984 a v zimním období 1984 - 1985 .

Stav infekčních a invazních chorob vyšetřovaných ryb je podrobně popsán $\mathrm{v}$ této práci.

Pro tlumení chorob u kapra obecného byly ověřeny některé krátkodobé koupele a pro zabránění hynutí ryb nedostatkem kyslíku byla navržena reálná opatření.

\section{Состояние здоровья рыбы в Мүшовском водохранилище}

В процессе исследования состояния здоровья рыбы в Мушовском водохранилище, проводимого в 1981 - 1985 гг. У хозяйственно ценных видов (Esox lucius, Ctenopharyngodon idella, Tinca tinca, Cyprinus carpio, Stizostedion lucioperca), были выявлены 2 инфекционных заболевания, 40 возбудителей инвазионных заболеваний и несколько болезненных состояний, У низкокачественных видов (Rutilus rutilus, Leuciscus idus, Scardinius erythrophthalmus, Alburnus alburnus, Blicca bjoerkna, Abramis brama, Carassius carassius, Perca fluviatilis, Gymnocephalus cernua) - $\frac{4}{\text { инфекционных }}$

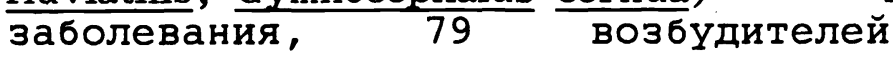
заболеваний и несколько болезненных состояний. Комплекс установленных паразитов $y$ хозяйственно ценных видов рыбы не достигал численности выявленных видов в ранее проводимых исследованиях, опубликованных в приводимых в литературном обзоре работах.

В ходе исследования в упомянутой местности имело место несколько аварий, вызванных нехваткой кислорода, растворенного в воде. Самая крупная авария, выловшаяся почти в полное уничтожение 
рыбы в водохранилище, имела место в январе 1984 г. и В зимнйй период 1984 - 1985 гг.

В данной работе дается подробное описание состояния инфекционных и инвазионных заболеваний исследуемой рыбы.

С целью приглушения заболеваний сазана проверялись некоторые кратковременные ванны и с целью предупреждения уничтожения рыбы по поводу нехватки кислорода были предложены реальные меры.

\section{References}

BAUER, 0. et al.: Bolezni prudovych ryb. Moskva, Lagkaja i piščevaja promyšlennos $\bar{t} 1981,318 \mathrm{p}$.

BAUER, 0 . et al.: Opredělitěl parazitov presnovodnych ryb fauny SSSR. T. 1. Prostějšije. Leningrad, Nauka 1984, 428 p.

BAUER, 0 . et al.: Opredělitěl parazitov presnovodnych ryb fauny SSSR. T. 2. Parazitičeskije mnogokletočnyje. Leningrad, Nauka 1985, 424 p.

BYCHOVSKIJ, B. E. et al.: Opredělitěl parazitov presnovodnych ryb SSSR. Moskva - Leningrad, Izdatělstvo Akademii nauk SSSR 1962, 776 p.

DYK, V.: Nemoci našich ryb. Praha, ČSAV 1954, 391 p.

DYK, V.: Nemoci ryb. Praha, CSAZV a SZN 1961, 404 p.

ERGENS, R.: Přispěvek $k$ poznáni cizopasniků ryb Vranovské přehrady. Spisy PFMU v Brně, 372, 1956: 1 - 8

ERGENS, R.: Výsledky výzkumu monogenetických motolic rodu Dactylogyrus Diesing, 1850. Práce Brněnské základny ČSAV, 28, 1956: 346 - 376

ERGENS, R. - LOM, J.: Pưvodci parasitárnich nemoci ryb. Praha, Nakladatelstvi CSAV 1970, $383 \mathrm{p}$.

HETEŠA, J. - SUKOP, I.: Znečištěni a kyslikový režim nádrži u Nových Mlýnù $z$ hlediska chovu ryb. In: Tvorba a ochrana životniho prostředí. Sborník ČSVTS, Ceské Budě jovice 1982: 46 - 53

HETEŠA, J. - SUKOP, I.: Hydrobiologické poměry horni zdrže VD Nové M1ýny po ekologické havárii $v$ roce 1984. In: Poznávanie, kvalitativne a kvantitativne hodnotenie vodných ekosystémov. Sbornik VII. konferencie ČsLS, Nitra 1985: $326-329$

LIBOSVÁRSKÝ, J. - SAEED, D. W.: Impact of a newly built reservoir on growth rate of roach. Folia zool. Brno, 32, 1983: 167 - 178

LUCKÝ, Z.: An investigation of invasive diseases of the fry of herbivorous fishes and their treatment. In: Fish, pathogens and enviroment in European polyculture. Szarvas 1981: $259-269$

LUCKÝ, Z.: Veterinárni péče v chovu ryb. Pardubice, ÚVO 1978, 208 p.

LUCKÝ, Z.: Metodické návody $k$ diagnostice nemoci ryb. Praha, SPN 1982, $150 \mathrm{p}$.

LUCKÝ, Z. - JIRÁSKOVÁ, M.: Výzkum rozšiření a patogeneze vývojovẏch stadii plochých červu cizopasicich u ryb ve státnich přirodnich rezervacich na Jižni Moravě. Project report, University of Veterinary Science Brno, 1975, 46 p. 
LUCKÝ, Z. - JIRÁSKOVÁ, M. - HAVRÁNEK, M.: Výzkum invaznich chorob býložravých ryb a jejich účinná prevence. Project report, University of Veterinary Science Brno, 1980, 41 p.

LUSK, S.: Rybár̆ské obhospodařováni horní zdrže vodního díla Nové Mlýny na řece Dyji. Živočišná výroba, 29, 1983: 1943 - 1051

LUSK, S.: Ichtyologické poměry $v$ oblasti horni zdrže $v$ obdobi před a $v$ prvnich dvou letech po napuštěni. In: Heteša, J. - Marvan, P.: Biologie nově napuštěné nádrže. Studie ČSAV 3, 1984: 120 - 129

OPRAVILOVÁ, V.: Zur Kenntnis des Entwicklungszyklus von Holostephanus cobitidis n sp. (Trematoda: Cyathocotylidae). Věst. čs. spol. zoolog.,
32, 1968: 46-65

PEJCOCH, M.: tbersicht der Arten der Gattung Diplozoon Nordman, 1832 (Discocotylidae, Monogenoidea). Scripta F. S. N. UJEP Brno, Biologia 5,4 1974: $171-178$

RAŠfN, K.: Dvě poznámky o Cystoopsis acipenseris. Biologické spisy vŠv, 9, 1930: $1-12$

RAŠfN, K.: Cocconema šulci n. sp. (Microsporidia), cizopasnik vajiček jesetera malého (Acipenser ruthenus L.). Věstnik čs. spo1. zoolog.,, , 1949: $295-298$

SCHÄPERCLAUS, W. et al.: Fischkrankheiten. Berlin, Akademie Verlag 1979, $1989 \mathrm{p}$.

VEJNAR, F.: Přispěvek $k$ helmintofauně našich okounovitých ryb. Sborník VŠLL, B, 4, 1965: $53-61$

VOJTKOVÁ, L.: Přispěvek $k$ poznáni cizopasniků ryb řeky Svitavy a Svratky. Pub1. Fac. Sci. Univ. Brno, 401, 1959: 97 - 123

VOJTEK, J. - FOLKMANOVÁ, B. - ERGENS, R.: Přispěvek k poznáni cizopasníků ryb jižni Moravy. Práce Brněnské základny CSAV, 26, 1954: 1 - 24. 